\title{
Marine turtle interaction with purse-seine fishery in the Atlantic and Indian oceans: Lessons for management
}

\author{
Jérôme Bourjea ${ }^{a},{ }^{*}$, Sandra Clermont ${ }^{\mathrm{a}, \mathrm{b}, \mathrm{c}}$, Alicia Delgado ${ }^{\mathrm{d}}$, Hilario Murua ${ }^{\mathrm{e}}$, Jon Ruiz ${ }^{\mathrm{e}}$, \\ Stéphane Ciccione ${ }^{b}$, Pierre Chavance ${ }^{\text {f, }}$
}

\begin{abstract}
a IFREMER, Institut Français de Recherche pour l'Exploitation de la Mer, Délégation de La Réunion, Rue Jean Bertho, BP 60, 97822 Le Port Cedex, La Réunion, France

${ }^{\mathrm{b}}$ KELONIA, l'observatoire des tortues marines de La Réunion, 46 rue du Général De Gaule, 97436 Saint Leu, La Réunion, France

${ }^{c}$ AgroParisTech, Institut des sciences et industries du vivant et de l'environnement, 16 rue Claude Bernard F75231, Paris Cedex 05, France

d IEO, Instituto Español de Oceanografía, Vía Espaldón, Darsena Pesquera, PCL 8, 38180 Santa Cruz de Tenerife, Spain

e AZTI Tecnalia, Unidad de Investigación Marina, Herrera kaia portualdea z/g, Pasaia, Gipuzcoa, Spain

${ }^{f}$ IRD, Institut de Recherche pour le Développement, Avenue Jean Monnet, CS 30171, 34203 Sète, Cedex, France
\end{abstract}

\footnotetext{
*: Corresponding authors : Jérôme Bourjea, tel.: +262 (0) 692656296 ; email address : jerome.bourjea@ifremer.fr ; Pierre Chavance, tel.: +262 262420340 ; fax: +262 262433684 ; email address : pierre.chavance@ird.fr
}

sandra.clermont@agroparistech.fr ; alicia.delgado@ca.ieo.es ; hmurua@azti.es ; jruiz@azti.es ; stephaneciccione@kelonia.org

\begin{abstract}
:
Bycatch of endangered marine turtles is a growing issue for the management of all fisheries, including the oceanic purse-seine fishery. The aim of this study was to assess the spatial and temporal variation in bycatch rates of these species in the entire European purse-seine fishery operating in the Atlantic and Indian oceans. The study was based on data collected through observer programs from 1995 to 2011. During that period, a total of 15913 fishing sets were observed, including 6515 on Drifting Fish Aggregating Devices (DFADs) and 9398 on free swimming schools, representing a global coverage of $10.3 \%$ and $5.1 \%$ of the total fishing activity in the Atlantic and Indian Ocean, respectively. Moreover, from 2003 to 2011,14124 specific observations were carried out on DFADs to check turtle entanglement in the net covering DFADs. We found that the purse-seine fishery has a very low impact on marine turtles. We estimated that the annual number of individuals incidentally captured was 218 $(S D=150)$ and $250(S D=157)$ in the Atlantic and Indian Ocean, respectively, with more than $75 \%$ being released alive. The present study also investigated the impact of DFADs; which is considered a key conservation issue for this fishery. Drifting objects may play a key role in aggregating juveniles of marine turtles, implying the need for improving their construction to avoid entanglement (e.g. avoiding nets in the structure); however, based on our study it is not the main source of incidental captures of marine turtles in this fishery.
\end{abstract}




\section{Graphical abstract:}

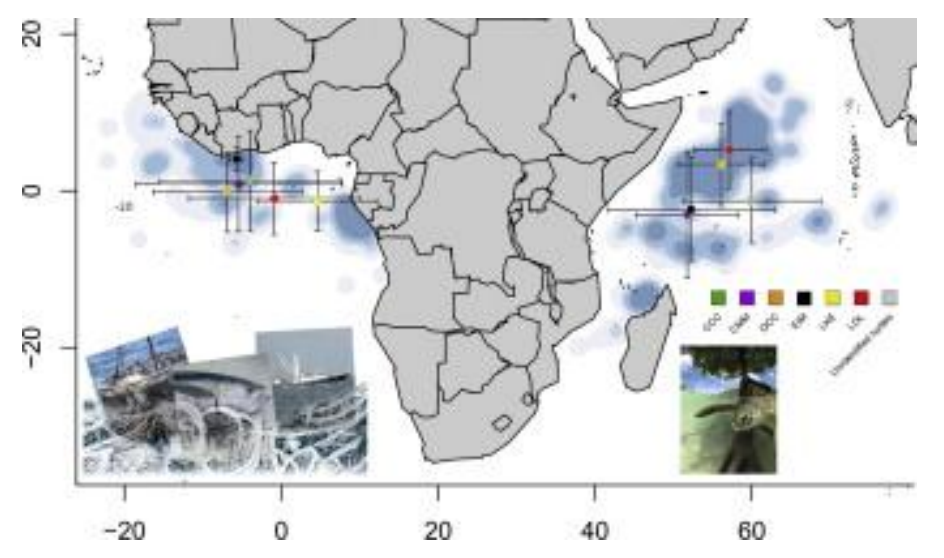

\section{Highlights}

We examine marine turtle interaction with purse-seine fishery in Atlantic and Indian oceans. We used 17 years of data from observers programs. Purse-seine fishery has a very low impact on marine turtle in both oceans. Drifting objects may play a key role in aggregating juveniles of marine turtle. Drifting Fish Aggregating Devices are not the main source of incidental captures of marine turtles.

Keywords: Bycatch ; Marine turtle ; Fishery impacts ; Fishery management ; Atlantic Ocean ; Indian Ocean 


\section{Introduction}

Marine ecosystems are extensively affected by human activities and require urgent implementation of management and conservation measures for marine resources (Halpern et al., 2008). The environmental and economic concerns about the impacts of fisheries on these ecosystems and associated marine populations are growing. Fisheries can alter habitats, and disturb the community structure by increasing mortality and modifying the population composition which consequently, may affect the whole ecosystem (Jennings and Kaiser, 1998; Hall et al., 2000; Jackson et al., 2001; Pauly et al., 2005). Bycatch, i.e. the incidental catch of undesirable size or age classes of the target species (e.g. juveniles), or the incidental catch of other non-target species (Lewison et al., 2004) has such negative impact. Large marine vertebrates, such as marine turtles, marine mammals and seabirds, with little or no commercial value, accidentally interact with a large range of fishing gears, resulting in injury or possible individual death (Hall et al., 2000). However, assessing the real impact of bycatch on large marine vertebrate populations is challenging. Sea turtle bycatch tends to be a relatively rare event, with most observed fishing sets containing zero bycatch, and most events clustered within the relatively few sets that overlap animal aggregations (Sims et al., 2008).

Six of the seven marine turtle species are listed as Vulnerable, Endangered or Critically Endangered on the IUCN Red List (www.iucnredlist.org; accessed 30 July 2012). Marine turtles are captured in most of fishing gears (Alverson et al., 1994) but little is known about the real level of associated mortality. The long oceanic migration of most marine turtles (see review in Luschi, 2013) leads them to interact with open ocean fisheries worldwide; however, the lack of global understanding of the movement between the successive habitats and the level of interactions with fisheries preclude the implementing of appropriate management measures to significantly reduce fisheries related mortality. A need of a "region-gear" combination that warrant urgent conservation measures needs to be adopted.

Tuna (or swordfish) drifting longline fishery, the drifting gillnet fishery and the oceanic purseseine fisheries are among the most economically valuable open sea fisheries in the Atlantic and Indian oceans. In both oceans, information is available regarding interaction with marine turtles for both longline and gillnet fisheries (see Hall et al., 2000; Lewison et al., 2004; Moore et al., 2008; Wallace et al., 2008, 2010; Lewison et al., 2014 ), but little is currently published regarding the real impact of the purse-seine fishery on marine turtles. In 2012 the fishery recorded around 307000 tons of tuna in the Atlantic and 356000 tons Indian Ocean and is dominated largely by the European Union (EU) fleets composed of Spanish and French vessels. The purse-seine fishing technique consists of surrounding the tuna school with a purse-seine net either on a free swimming school (FSC) or on a school aggregated under a floating object, called a Drifting Fish Aggregating Device (DFAD; Fonteneau et al., 2013). This technique may negatively impact biodiversity (Dagorn et al., 2013).

Although tuna purse-seine fisheries have been shown to be more selective than other fisheries (Alverson et al., 1994), several species, including vulnerable and sensitive species can be incidentally caught (e.g. Amandè et al., 2010). Many reports and other grey literature sources have already implied that the purse-seine fishery has few interactions with marine turtles in three major oceans (see review in Hall and Roman, 2013). However with low observer coverage and encounters usually less than 1 percent of sets, it is difficult to produce solid estimates of sea turtle mortality that can be attributed to the purse-seine fishery (Sánchez et al., 2007; Hall and Roman, 2013). In fact, marine turtle bycatch may appear to be a rare event in most fisheries because marine turtles do not follow the assumptions most commonly used that discards are proportional to catch or to effort, and depend on environmental conditions and fishing methods (Rochet and Trenkel, 2005; Amandè et al., 2012). Such environmental dependence is particularly noticeable in the case 
of interaction between marine turtles and the purse-seine fishery because of (1) the oceanic range of purse-seine fishing operation (IOTC-SC15, 2012), (2) the complex life cycle of marine turtles (Miller, 1997), (3) their great migratory capability (Luschi, 2013), and (4) the lack of knowledge about the pelagic phases of those species.

In order to identify the key issues related to purse-seine fishery interaction with marine turtles, the present paper focuses on the description of interactions between marine turtles and the European purse-seine fishery in the Atlantic and Indian oceans using 15 years of data from at-sea Spanish and French observer programs.

\section{Materials \& Methods}

\subsection{Datasets}

Under the European Data Collection Regulations (Council Regulation $n^{\circ}$ 1543/2000, Commission Regulation $n^{\circ} 1581 / 2004$, Council Regulation $n^{\circ} 199 / 2008$, and Commission Decision 2008/949/EC), the European Union established a mandatory sampling program to estimate the amount of bycatch and discards in the European Union fisheries. The French (Institut de Recherche pour le Développement - IRD) and Spanish (AZTI Tecnalia and Instituto Español de Oceanografía - IEO) research institutes collaborated to implement a common framework for collecting and analysing the data from observer programs conducted on the tropical tuna purse-seine fisheries operating in the Atlantic and Indian oceans. The observers were opportunistically placed onboard purse seiners vessels in order to cover equally the four quarters of fishing activity. The observers collected information of fishing activities, target species catches, amount of bycatches by species and size frequencies of bycatches. The information collected by observers is introduced in a common database from which the data presented in this paper were extracted (e.g. Chavance et al. 2012; for more details contact authors). Spain and France started their cooperative observer programs in 2003 and in 2005 respectively. Moreover, data from other past observer programs implemented by each country and based on the same methodology were also included in the database and analysed here (Table 1).

Although observer programs before the implementation of European Union Data Collection Regulation were slightly different, these historical programs were all conducted under the International Commission for the Conservation of Atlantic Tunas (ICCAT) aegis or within European project (table 1). Observation protocols were developed focusing on the same objective (i.e. estimation of bycatch) and were implemented simultaneously by the different institutes. Data from these different programs were then aggregated. Pianet et al. (2000) showed that Spanish and French purse-seiner use similar technology and have similar fishing strategy. Catches by species and by size category are not different between countries when fishing in the same strata defined by large statistical areas, quarters and fishing modes (free school set vs Fish Aggregating Device sets). Therefore, we assume that there are no significant differences in the level of interaction with marine turtles between both fleets and between vessels. Finally, as both countries share the same observer programs and observer training technics since their implementation, we assume that errors due to the numerous different observers were similar from both French and Spanish observer programs.

Moreover, French and Spanish purse-seine fishing activities (FSC vs. DFADs) made available $100 \%$ coverage of logbook databases for this study and for all years analysed. 


\subsection{Data Collection}

Data are collected by observers on an exact position basis (latitude and longitude) and aggregated for the analysis by $1^{\circ}$ statistical square when needed. Observers collected the data during observer trips when a fishing set is carried out and when a drifting object is visited. Observations on sets give information on turtle bycatch during a set on Free Swimming School (FSC) or Drifting Fish Aggregating Device (DFAD). Observations on drifting object, without associated fishing set, can also occur when the object is just visited. During a visit, the object can be hauled onboard or not. In the latter case the entanglement of turtles in the deeper part of the net hanging underneath the DFAD cannot be annotated by the observer. Filmalter et al. (2014) did 51 diving observations under DFAD in the Indian Ocean and estimated significant sharks entanglement in the lower part of DFADS. However, during these observations, Forget (comm. pers) counted two turtles entangled on the superior part of the DFAD and therefore not hidden from observers, but does not find any turtle entangled underneath DFADs.

As drifting objects are not individually identified and as their position can change, one object can be observed several times. The observer takes note of the presence, absence and/or entanglement of any animal, including turtles and their fate. Data from observed purse-seine sets range from 1995 to 2011 whereas data from object observations range from 2003 to 2011.

When marine turtle bycatch occurs, observers reported the exact date, GPS position and numbers of individuals by species. Species identification remains a key issue for validation in the database. Observers have specific training before going at sea that includes marine turtle species identification. When a doubt occurs while onboard, observers take various photos for cross validation by experts. Marine turtles were not systematically measured. For the one measured (Carapace Curved Length - CCL), it was possible to assess the maturity stage according to species size-at-maturity data available in the literature. If the size was below maturity, we considered that the individual was a juvenile. Finally, observers also noted the fate of the turtle (alive or dead) when returned to the sea.

Before analysing the dataset, a quality control procedure was applied to the datasets to check inconsistencies when data were entered in the database. Doubtful data which could not be corrected were discarded from the database, such as incorrect $1^{\circ}$ statistical squares, isolated typos and duplicated observations.. Marine turtle data (i.e. species, location, size ...) were also checked one by one and compared to the literature to identify any inconsistency with known species biology such as maximum size and distribution. In such cases, the observation was corrected if possible or eliminated.

\subsection{Analysis and mapping}

Data were categorized using two fishing modes (DFAD or FSC) that are known to explain most of variability in bycatch in purse-seine fishery (Delgado de Molina et al., 2000; Romanov, 2002; Sánchez et al., 2007; Amandè et al., 2010). However, analyses were performed for ocean basins because (1) marine turtle are identified in separate Regional Management Units in both oceans (Wallace et al., 2011), (2) there is currently little information showing any connectivity between marine turtle stocks in the Atlantic and Indian oceans (e.g. for green turtle, see Bourjea et al., 2007) and (3) the spatial distribution of catch and effort from European purse-seine in both oceans are very different (e.g. IOTC, 2012). In order to assess a spatial and temporal effect on marine turtle bycatch, observed data were stratified per $1^{\circ}$ statistical square, year and quarters. Whenever possible, analyses per species composition and maturity stage were also spatially conducted. 
In order to avoid bias from the observation effort, we weighted marine turtle observations to the total observation effort. To obtain the number of observed turtles per observed set or per observed object per year, we worked at the $1^{\circ}$ statistical square and divided the total number of observed turtles by the total observed sets or object observed per year. The annual mean of observed turtles per observed set or object and respective standard deviation were then calculated per ocean and per fishing mode.

To observe the spatial distribution of marine turtle bycatch by species, the latitudinal and longitudinal barycentres of turtle bycatch or observed turtles on object were calculated yearly for each species in both oceans. GPS positions of bycatch were used to estimate the Utilisation Distribution of interaction (UD) with the kernels method (Worton, 1989, 1995). The Utilization Distribution is the bivariate function giving the probability density of the animal to be found at a point according to its known geographical coordinates. Using this method, a home range can be estimated as the minimum area in which an animal has some specified probability of being located. The functions we used here correspond to the approach described in Worton (1995) and implemented using $\mathrm{R}$ (adehabitat and maps packages). All maps were drawn using Arcgis 10.2 and statistics analyses were performed using $R$ software (R Core Team, 2013).

\subsection{Data extrapolation}

We carried out a tentative extrapolation of the observed bycatch data to the total fishing effort per year and oceanic region in order to have an order of magnitude of the total number of marine turtles incidentally caught by the purse-seine fishery in the Atlantic and Indian oceans. We used information derived from French and Spanish fishing statistics logbooks to determine a raising factor based on the effort of the fleets (number of sets on FSC and DFAD per $1^{\circ}$ square and per year). In this way, we established an estimation of the total marine turtle bycatch based on information during observed sets. Since there is no available information on the total number of DFAD deployed by the European purse-seine fishery, it was not possible to raise the data to the total number of DFADS to estimate the real impact on turtle's interaction with drifting DFAD.

\section{Results}

\subsection{European purse-seine fishing and observation efforts}

From 1995 to 2011, more than 213000 sets were undertaken by the European purse-seine fleets in both the Atlantic and Indian oceans and reported in logbooks (Tables 1 and 2). A total of 15913 purse-seine sets on DFAD and FSC from 1995 to 2011 and 14123 drifting objects from 2003 to 2011 were observed by onboard observers (Tables 1 and 2). The average yearly observer coverage of the purse-seine nets was significant with $10.0 \%$ $(S D=7.9)$ in the Atlantic and $8.9 .3 \%(S D=9.1)$ in the Indian Ocean of the purse-seine sets observed over this period (Table 2).

As the observers were placed onboard fishing vessels to cover equally the $4^{\text {th }}$ quarters of fishing activity, we assumed that observer sets are representative of the total fleet effort. In fact, observed sets distribution overlap with fishing sets distribution (Figure 1A-B and 2A-B); which support this assumption. The coverage of fishing set observation varied greatly from 1995 to 2011 in both oceans and between and within the observed fishing mode (Table 2). For instance, the sampling coverage between oceans is different in 2010, with an Atlantic coverage $(11.4 \%)$ higher than that of the Indian Ocean $(8.3 \%)$. Similarly, there is different coverage between fishing modes in 2010 , with sets on FSC being more extensively covered $(10.6 \%)$ than sets on DFAD $(7.6 \%$; Table 2$)$. Besides, the level of total sets on FSC is 
almost the same in the Atlantic (50 914 sets) and Indian (52 531 sets) oceans (Table 2), but double the observed sets were carried out on FSC in the Atlantic, due to the fact that European purse-seine fishery used to fish twice as much on DFAD in the Indian Ocean (61 734 sets) than in the Atlantic Ocean (35 727 sets; Table 2). This difference in fishing strategy on DFAD between oceans is not taken into account in the observation effort since there are around 3000 set observations on FAD in both oceans (Table 2).

The comparison of the spatial and temporal distribution between purse-seine sets and observed sets was already discussed in Amandè et al. (2008, 2012; see also supplement material for temporal distribution of effort and observer coverage); thus, we provide here only the global picture of those distributions. The spatial coverage of the observer programs in term of sets on FSC seems to contribute good coverage of the whole fishing area and effort (Fig. 1AB and supplement material). The coverage for DFAD is well distributed in the Atlantic Ocean, but in the Indian Ocean, we noted that the Mozambique Channel is over represented compared to the North-Western Indian Ocean (Fig. 2AB). Per quarter, the observation coverage seems also to not detect any significant discrepancies with the fishing area and effort in both oceans (see Supplement Material). In the Indian Ocean, the fishing effort is concentred in the Mozambique Channel during the end of the first and all the second quarters, before moving to the north western in the third, fourth and beginning of the first quarters. In the Atlantic Ocean, the fishing effort does not display any strong spatial pattern along the year.

In addition to the observed fishing sets, more than 14000 drifting objects were also directly observed in both oceans from 2003 to 2011 (66\% in the Indian Ocean; 34\% in the Atlantic Ocean; Table 2). By comparing the fishing effort on DFAD to the observation of drifting objects (Fig. 2A and $3 A$ ), the object observation effort seems to adequacy cover the total fishing effort on DFAD in Atlantic Ocean, but in the Indian Ocean the north Mozambique Channel remains again over observed.

\subsection{European purse-seine marine turtle bycatch on observed sets}

Out of the 15913 sets observed from 1995 to 2011, 597 marine turtles were accidentally caught, 415 and 182 in the Atlantic and Indian oceans respectively (Table 2). Even if the average annual number of bycatch per number of observed sets in the Atlantic $(0.04$, $S D=0.02)$ and Indian $(0.03, S D=0.02)$ oceans is similar (t-test, $p>0.05)$, there is a significant difference in the number of bycatch according to the fishing mode, only in the Indian Ocean, with an annual average number bycatch per observed sets on FSC smaller () than on DFAD ( $0.05, \mathrm{SD}=0.04$ and $0.1, \mathrm{SD}=0.01$ respectively; t-test, $\mathrm{p}<0.001$ ).

More than $76 \%$ of the turtles were identified and $93 \%$ were allocated a fate (Table 3 ). Upon the 597 turtles accidentally caught, $91 \%$ and $77 \%$ were released alive in the Atlantic and Indian oceans respectively, which represents 21 and 20 dead turtles observed in the Atlantic and Indian oceans, respectively, over the period (Table 3). In both oceans, the percentage of marine turtles returned to the sea alive is very similar between DFAD and FSC (respectively $92.0 \%$ and $89.3 \%$ in the Atlantic Ocean, and $76.4 \%$ and $79.4 \%$ in Indian Ocean). Lepidochelys sp., both Kemp's Ridley and olive are the most frequently encountered in both oceans with 172 observations; followed by loggerhead (Caretta caretta; $\mathrm{N}=73$ ) and leatherback (Dermochelys coriacea; $\mathrm{N}=67$ ) turtles in the Atlantic Ocean whereas in the Indian Ocean they are followed by hawksbill (Eretmochelys imbricata; $\mathrm{N}=37$ ) and green turtles (Chelonia mydas; $\mathrm{N}=32$ ). Bycatch of leatherback turtles remains rare in the Indian Ocean with only two observations from 1995 to 2011.

The size and the life stage were determined for 352 of the marine turtles, with $68 \%$ estimated to be adults in the Atlantic while most turtles were juvenile in the Indian Ocean (74\%; Table 4). 


\subsection{European purse-seine marine turtle bycatch on observed floating objects}

From 2003 to 2011, 354 marine turtles were recorded on 14124 floating objects, 116 of which were in the Atlantic Ocean and 238 in the Indian Ocean (Table 2). The mean number of observed turtles per object per year is very similar in the Atlantic Ocean $(0.019, S D=0.015)$ and the Indian Ocean $(0.022, S D=0.016)$; which is lower than the mean number of marine turtles observed per set and year (Table 2).

Of the observed marine turtles on floating objects, $74 \%$ were identified. In the Indian Ocean, the species composition is very similar to the one observed on purse-seine sets: the dominant species is olive Ridley (Lepidochelys olivacea; $\mathrm{N}=74$ ), followed by the hawksbill $(\mathrm{N}=40)$ and the green turtle $(\mathrm{N}=37)$ (Table 5). As for fishing set observations, occurrence of leatherback turtle is rare $(\mathrm{N}=6)$. In the Atlantic Ocean, the most observed turtles are again the two species of Lepidochelys (41 olive Ridley and 12 Kemp's Ridley turtles). No difference was observed between the 4 other species that are rarely caught $(<8)$. Most of the turtles observed at a floating device were alive whilst still entangled or already free. Hence, $93 \%$ and $73 \%$ of the individuals were released alive in the Atlantic and Indian oceans respectively, which is similar to the values found on purse-seine sets for both oceans (Tables 5).

\subsection{Spatial distribution of marine turtle bycatch on observed sets}

Over the study period and in both oceans, the areas where interactions between European purse-seine and marine turtles occur cover the entire fishing zones (Fig. 4AB, see also supplement material for temporal effect), and are illustrated by the estimated utilisation distribution of observed bycatch using a kernel approach (Fig. 5A). This approach allows us to suggest that, even if interaction occurs in all the fishing area in the Atlantic Ocean, there are clearly defined hotspots of interactions in the Indian Ocean, e.g. off the coast of Somalia and in the northwest Madagascar. Due to the low number of interaction, and the number of species of marine turtle that interact with this fishery, temporal distribution of marine turtle bycatch over the year was not investigated (see supplement material for maps per quarter).

In order to assess a spatial pattern per species, we plotted the barycentres of the turtle bycatch for each species in both oceans (Fig. 5A). In the Atlantic Ocean, the distributions do not show any specific spatial pattern. The olive Ridley $(\mathrm{N}=76)$ and Kemp's Ridley $(\mathrm{N}=37)$ turtles are accidentally captured in the eastern area of the fishing zone while leatherback $(\mathrm{N}=67)$, loggerhead $(\mathrm{N}=73)$ and green $(\mathrm{N}=40)$ turtles are mainly found in the western area. In the Indian Ocean, although there are also large standard deviations, both in longitudes and latitudes, a clearer spatial distribution by species in relation to fishing activity is observed. The olive Ridley $(\mathrm{N}=58)$ is clearly found more in the northern area while hawksbill $(\mathrm{N}=37)$ and green $(\mathrm{N}=32)$ turtles are found more in the southern part of the fishing area. These two species are also the only ones observed in the Mozambique Channel (Fig. 4). The loggerhead turtle $(\mathrm{N}=19)$ is distributed mainly in the northern area which in the Indian Ocean is limited between the Mozambique Channel and Somalia. Such observations are highlighted in distribution estimations using the Kernel approach in both oceans by species

Bycatch of marine turtles per unit of observation effort (i.e. observed sets) from 1995 to 2011 are shown in Fig. $1 \mathrm{C}$ and $2 \mathrm{C}$. The mean number of by-caught turtles per observed sets was very low in both DFAD and FSC sets $(<0.044$ turtles; SD $<0.029)$ in the Atlantic and Indian oceans $(<0.056$ turtles; $S D<0.034)$, meaning that most of the time, captures per set rarely account to more than a single individual (Table 6). The highest capture rates on DFAD and FSC occur in the North Western Indian Ocean but are low in the Mozambique Channel even with a higher observation effort. In the Atlantic, accidental captures occur more or less in all the fishing areas with a high level of bycatch per unit of observed effort off the Guinea coast. 


\subsection{Spatial distribution of marine turtle bycatch on observed objects}

As for observation on purse-seine sets, marine turtles interacted with floating objects in the whole Atlantic and Indian oceans fishing area (Fig. 3A and 5B). In the Indian Ocean, we observed the same pattern as for set observations, with the highest turtle observation rates located in the Northern area (Somali basin) while no specific pattern was observed in the Atlantic (Fig. 3B).

We also plotted barycentres of the observed turtles for each species in both oceans (Fig. 5B) and we found a similar pattern as observed for purse-seine sets: the distributions of different turtle bycatch almost completely overlap in the Atlantic with the olive ( $N=41)$ and Kemp's Ridley ( $\mathrm{N}=12)$ being observed more towards the eastern area (Fig. 5B). However, the hawksbill distribution $(\mathrm{N}=6)$ is located in the northern fishing area and seems to be less dispersed than the other species $(\mathrm{CCC}=7, \mathrm{CMM}=6, \mathrm{DCC}=8, \mathrm{LKE}=12$ and $\mathrm{LOL}=41)$. In the Indian Ocean the same pattern as for sets was observed, with hawksbill $(\mathrm{N}=40)$ and green $(\mathrm{N}=37)$ turtles more often observed in the southern area while the olive Ridley $(\mathrm{N}=74)$ observations on objects were located more towards the Northern Indian Ocean. Loggerhead $(\mathrm{N}=18)$ and leatherback $(\mathrm{N}=6)$ turtles were observed in northern latitudes.

\subsection{Total EU marine turtle bycatch estimation}

Using the number of accidentally captured marine turtles per observed sets by year, by fishing mode and the total fishing effort in number of sets available for the European purseseine in both oceans, an estimation was produced of the order of magnitude of the total number of marine turtles interacting with the European purse-seine fishery (Table 6). The total incidental capture of marine turtles was estimated at 3849 individuals in the Atlantic Ocean over the period from 1995 to 2010 and 2581 in the Indian Ocean for 2003-2011. Based on marine turtle survival rate estimated using observed data on purse seine sets, we estimated that 222 and 390 marine turtles died in the Atlantic and Indian oceans respectively over those 17 and 9 years periods respectively (Table 3). On average, we found that the annual European purse-seine bycatch rate for marine turtles was $226(S D=148)$ and 235 $(S D=153)$ in the Atlantic and Indian oceans respectively, which corresponds to an estimated average annual death of $13(S D=22)$ and $35(S D=39)$ marine turtles in the Atlantic and Indian oceans. Even with a large standard deviation due to the low observation rate, it is estimated that this fishery kills less than 50 marine turtles per year for both oceans combined.

\section{Discussion}

\subsection{Global marine turtle bycatch assessment in European purse-seine fishery}

Based on data from observer programs and logbook data from 1995 to 2011, this study presents an attempt to evaluate the global bycatch on marine turtles of the European Union oceanic purse-seine fishery operating in the Atlantic and Indian oceans.

Observations were carried out using a significant number of purse-seine sets with observers (15 913 sets) and direct observations on floating objects (14 123 objects) used by this fleet to catch tuna and tuna-like species. The average annual observed sets is quite an important sample of the fishing activity for such an industrial fishery (Atlantic Ocean: $10.0 \%$ (SD=7.9); Indian Ocean: $9.3 \%$ (SD=9.4) (Table 2)) even if it is still below the optimal level necessary for an accurate estimation of the total bycatch (Hall and Roman, 2013). Amandè et al. (2008, 2012) showed that the current sampling coverage in the observer programs of the European purse-seine fishery resulted in large uncertainties in precision and accuracy of bycatch estimates by species. As marine turtle bycatch was reported to be rare events (Sims et al., 2008, Amandè et al., 2012), the coverage rate should even be higher to allow a good 
estimation of the impact on these endangered species. For instance, in the case of whales, the required observer coverage is $100 \%$ for the Atlantic shark gillnet fishery, during those times of the year when whales are calving (NMFS, 2002). In the Pacific Ocean, purse-seine observer programs have covered 20 to $100 \%$ of the fishing effort (Lennert-Cody et al., 2004; Hall and Roman, 2013). The coverage levels of at least $50 \%$ of total effort for rare species would give reasonably good estimates of total bycatch of rare species (see review in Babcock et al., 2003). These observation levels would be ideal to obtain a good estimate of bycatch levels, but however, are costly, given the availability of resources and economic or logistic constraints that allow only low sampling of the activity (Hall, 1999). Alternative ways to improve onboard surveillance should be investigated, such as electronic monitoring, which may make it possible to implement cost effective programmes and to increase observation coverage.

Despite uncertainties revealed by large standard deviations due to the rarity and highly variable events ( 1 to 5 turtles/set) and low sampling rates, we estimated that an average annual of $218(S D=150)$ and $249(S D=153)$ marine turtles were recorded as bycatch by the European purse-seine fishery in the Atlantic and Indian oceans respectively. This level of bycatch from European purse-seine remains very low in comparison to other open sea industrial fishery gears commonly used in both oceans: longline fishery that results in a substantial level of marine turtle bycatch (see review in Read, 2007; e.g. Lewison et al., 2004; Petersen et al., 2009), gillnet (e.g. Benhardouze et al., 2012) or bottom trawl fishery (e.g. Fenessy et al., 2008). For example, Casale et al. (2011) estimated that 39000 marine turtles are captured per year by the bottom trawl fleet in the Mediterranean and 23000 marine turtles are recorded as bycatch annually in the set nets fleet in the Mediterranean.

It has been demonstrated that the survival rates of marine turtle after an interaction with European purse-seine fishery are high, $0.95(S D=0.09)$ and $0.87(S D=0.15)$ in the Atlantic and Indian oceans, respectively, which can be compared with an estimation of $13(S D=22)$ and $37(\mathrm{SD}=40)$ individual deaths on average per year in the Atlantic and Indian oceans respectively. As for comparisons, Casale (2011) estimated that turtle mortality rate in the entire Mediterranean fleet were $20 \%, 30 \%, 40 \%$ and $60 \%$ for the bottom trawl, pelagic longline, demersal long-line and set net fisheries, respectively, leading to an estimated of annual total mortality of 44000 turtles. Being aware that the European purse-seine fishery represents $56 \%$ and $63 \%$ of the total purse-seine catches in the Atlantic and Indian oceans respectively over the 1995 - 2011 period (Chassot et al., 2013; Delgado de Molina et al., 2013), our estimates tend to indicate a very low impact of European purse-seine on marine turtle populations in comparison to other industrial fisheries or, at least, that is clearly not of the same order of magnitude as other fisheries. However, it is worthwhile noting that comparing the impact on marine turtle of different fisheries is very context specific and should take into account the abundance by species of the affected population (e.g. Dalleau et al. in press).

\subsection{Comparative impact of DFAD versus FSC}

Previous dedicated studies have suggested that interactions between purse-seine and tunalike species are mainly due to the increase attraction resulting from the netting materials used to wrap around and under the DFADs (Fonteneau et al., 2000; Sánchez et al., 2007; Amandè et al., 2008; 2010; Hall and Roman, 2013). The netting may act as protection from predators, a source of food (Gooding and Magnuson, 1967), or a meeting location (Fréon and Dagorn, 2000). The results from the present study do not support the assumption that DFAD is by far the main source of incidental captures of marine turtles in purse-seine fishery. Our findings for the Atlantic Ocean lead to the same conclusions as Hall and Roman (2013) in the Pacific Ocean, in that the mean number of by-caught turtles per observed set is very similar between fishing modes. However in the Indian Ocean, more turtles are observed when sets occur on DFADs than FSC. It seems difficult to explain such differences but also it 
was observed that catches of juveniles are significantly higher in the Indian Ocean (74\%; $\mathrm{N}=87$ ) while bycatch was largely dominated by adults in the Atlantic Ocean $(68 \% ; \mathrm{N}=159)$. Witherington et al. (2012) showed that several species of young marine turtles have been observed to aggregate on Sargassum-dominated drift communities and that their diet was composed principally of Sargassum-community associates. These observations lead us to hypothesize that juvenile marine turtles in their drifting pelagic phase, may be more attracted by DFADs looking for protection, food or a rest site rather than just drifting. The differences observed between the Atlantic and Indian oceans may only be a consequence of the abundance of open sea juvenile marine turtles in the fishing area. Models of drifting trajectories of immature marine turtles have been already developed in the Atlantic Ocean (Blumenthal et al., 2009; Monzón-Argüello et al., 2010; Lohmann et al., 2012; Proietti et al., 2012). On the one hand, juveniles born along the west African coast appear to be carried away towards America, and on the other hand, young marine turtles born on American beaches seem to remain in the northern hemisphere, leading to a low abundance of this stage of life that may interact with purse-seine gear.

It is worthwhile noting that in this study, observer data collection do not include possible turtle interaction and mortality from two sources: (i) turtles entanglement in the deeper part of the net hanging underneath the DFADs (as this cannot be seen by observers when a DFAD is visited but not hauled onboard) and (ii) the ghost fishing problem occurring when floating devices are lost. Pieces of net, hanging underneath the DFAD, are believed to be the cause of some marine turtle mortality by entanglement and subsequent drowning (see review in Hall and Roman, 2013). The cryptic mortality might be particularly serious when the lost DFADs drift closer to nesting locations leading to a significant mortality of marine megafauna (Shanker et al., 2004). However, information on the number of DFADs deployed is still lacking in the Atlantic and Indian oceans (Dagorn et al., 2013), with only some estimates for the Pacific Ocean (9 813 DFADS deployed 2008, WCPFC, 2009). Hall and Roman (2013) estimated that the additional mortality due to lost DFADs in the Pacific Ocean could be in the order of $80-100$ marine turtles per year. This should also be assessed in relation to the estimated 6400000 tons of different fishing gears lost each year (Wilcox et al., 2012). However, it is important to note that European Union purse seiners operating in the Atlantic and Indian oceans recently started using non-entangling DFADs with non-meshed material both in the surface structure and sub-surface component of the DFADs.

\subsection{Key conservation lessons from bycatch patterns}

In addition to the assessment of the global level interaction between purse-seine fishery and marine turtles in the Atlantic and Indian oceans and the impact of the different fishing modes, other key regional lessons can be drawn from this study in order to understand the spatial pattern and distribution of marine turtle species and life stages. For instance, the bycatch pattern observed for both hawksbill and green turtle is interesting to consider. These two species are mainly coastal species (Marquèz, 1990) which are found in the open sea only during breeding migrations (Limpus et al., 1992; Gaos et al., 2012) with a very specific behaviour which has them travelling fast and not feeding (Luschi et al., 2007; Benhamou et al., 2011). This has the effect of decreasing the chances of interaction with purse-seine activities. In contrast, juveniles use the pelagic habitats for a long period drifting within the dominant currents (e.g. Hamanna et al., 2011; Proietti et al., 2012), which increases their chances of interacting with purse-seine activity. Such behaviour may explain why juveniles of these two species are observed most frequently on purse-seine sets, both in the Atlantic and Indian oceans.

European purse-seine bycatch patterns also reflect the nesting distribution of species. It was noted for instance that interaction with the leatherback turtle in the Indian Ocean is a rare event whereas in the Atlantic Ocean it is one of the turtles most frequently captured by European purse-seiners. Such a result is a reflection of the nesting distribution of this 
species and its oceanic behaviour in both oceans. In the western Indian Ocean, nesting sites of leatherback are rare and small (Nel et al., 2013) and feeding grounds are located in higher latitudes out of the European purse-seine fishing activity (Luschi et al., 2006). The impact of the European purse-seine activity is thus expected to be limited. In contrast, the interaction results for the Atlantic Ocean are not surprising as there are two large nesting colonies in the eastern part of the Atlantic Ocean , hosting several tens of thousands of leatherback nesting in the Guinea and in the Gabon (see review in Eckert et al., 2012). Interestingly the two main hotspots of interaction with leatherbacks are observed off the coast of those nesting sites. A similar situation occurs with the olive Ridley in the Indian Ocean where increased interactions occur in the northern part of the European purse-seine fishing area (Figure 4). This correlates with nesting activity of this species in the Indian Ocean as the main nesting sites are situated in the northern hemisphere (Shanker et al., 2003) with few records of nesting from the south west Indian Ocean (Frazier, 1975).

Another interesting lesson came from the reporting by observers of Lepidochelys kempii. If we compare the normally accepted distribution in the Atlantic Ocean (Wallace et al., 2011), this species is not supposed to be found in the European purse-seine fishing area. It is therefore necessary to note that some turtle data, suggesting Kemp's Ridley turtles were recorded as by-catch, used in this study could be the result from misidentifications with the olive Ridley turtle as these two species are very difficult to differentiate. It is not suggested that all identifications are definitively wrong and this may be an opportunity to review the global distribution of the Kemp's turtle in the Atlantic Ocean using DNA samples of Lepidochelys sp. accidentally captured in this fishery.

It is suggested that the work done by observers on board purse-seiners, to monitor bycatch and improve our understanding of the interaction between this fishing activity and megafauna, would be highly advantageous to enhance large scale onboard observers programs by collecting tissue samples and associated biological parameters from vulnerable and migratory species such as marine turtles. Such a collection opens the door to solving key issues regarding species at sea distribution and the behaviour of turtles at all life stages. In the case of marine turtles, information provided by genetic sampling could contribute to a better understanding of the distribution of all stages of life based on their origin, i.e. identified Management Units or rookeries. Filling in this key gap could be a key advance in helping to mitigate the impact of bycatch by other fisheries.

\section{Acknowledgments}

The authors are grateful to the observers involved in data collection. They thank the fishing masters and their fishing companies for their close collaboration with the observers and IRD/IEO/AZTI scientists. These observer programs are co-financed by IRD/IEO/AZTI and the European Data Collection Framework (Reg EC 1543/2000 and 199/2008). We also thank L. Floch, P. Cauquil and A. Damiano (IRD) for database development and management. We wish to thank L. Hoarau especially, as well as M. Ropert and L. Maurel for their helpful advice on GIS and M. Dalleau for R implementation of geographical data.

\section{Literature cited}

Alverson, D. L., Freeberg, M. H., Murawski, S. A. and Pope, J. G. A. (1994) A global assessment of fisheries bycatch and discards. FAO Fisheries Technical Paper, 339-233. 
Amandè, J.M., Chassot, E., Chavance, P., Murua, H, Delgado de Molina, A. and Bez, N. (2012) Precision in bycatch estimates: the case of tuna purse-seine fisheries in the Indian Ocean. ICES Journal, 10 pp. doi:10.1093/icesjms/fss106.

Amandè, J.M., Lennert-Cody, C.E., Bez, N., Hall, M.A. and Chassot, E. (2008) How much sampling coverage affects bycatch estimates in purse-seine fisheries? IOTC-2008-WPEB20, 16 pp.

Amandè, M.J., Ariz, J., Chassot, E., Delgado de Molina, A., Gaertner, A., Murua, H., Pianet, R., Ruiz, J. and Chavance, P. (2010) Bycatch of the European purse-seine tuna fishery in the Atlantic Ocean for the 2003-2007 period. Aquatic Living Resources 23, 353-362.

Babcock, E., Pikitch, E. and Hudson, C. (2003) How much observer coverage is enough to adequately estimate bycatch? Report of the Pew Institute for Ocean Science. Miami, USA, Rosenstiel School of Marine and Atmospheric Science, University of Miami. 36 pp.

Benhamou, S., Sudre, J., Bourjea, J., Ciccione, S., De Santis, A. and Luschi, P. (2011). The Role of Geomagnetic Cues in Green Turtle Open Sea Navigation. Plos One 6(10): e26672.

Benhardouzea, W., Aksissoua, M. and Tiwari, M. (2012) Incidental captures of sea turtles in the driftnet and longline fisheries in northwestern Morocco. Fisheries Research 127-128, $125-132$

Blumenthal, J.M., Abreu-Grobois, F.A., Austin, T.J., Broderick, A.C., Bruford, M.W., Coyne, M.S., Ebanks-Petrie, G., Formia, A., Meylan, P.A., Meylan, A.B. and Godley, B.J. (2009) Turtle groups or turtle soup: dispersal patterns of hawksbill turtles in the Caribbean. Molecular Ecology 18, 4841-4853.

Bourjea, J., Lapègue, S., Gagnevin, L., Broderick, D., Mortimer, J.A., Ciccione, S., Roos, D., Taquet, C. and Grizel, H. (2007) Phylogeography of the green turtle (Chelonia mydas) in the Southwest Indian Ocean. Molecular Ecology 16, 175-186.

Casale, P. (2011) Sea turtle by-catch in the Mediterranean. Fish and Fisheries 12, 299-316.

Chassot, E., Delgado de Molina, A., Assan, C., Dewals, P., Cauquil, P., Areso, J.J., Rahombanjanahary, D.M. and Floch, L. (2013) Statistics of the European Union and associated flags purse seine fishing fleet targeting tropical tunas in the Indian Ocean 19812012. IOTC-WPTT-13, 44 pp.

Chavance, P., Damiano, A., Cauquil, P. and Relot, A. (2012) Observer program on the French tropical tuna purse seine fishery in the Atlantic Ocean. Collective Volume of Scientific Papers, 68(5), 2021-2024.

Cochran, W. G. (1977) Sampling Techniques, 3rd edn. John Wiley and Sons, New York.

Dagorn, L., Holland, K.N., Restrepo, V. and Moreno, G. (2013) Is it good or bad to fish with FADs? What are the real impacts of the use of drifting FADs on pelagic marine ecosystems? Fish and Fisheries 14(3), 391-415.

Dalleau, M., Benhamou, S., Sudre, J., Ciccione, S. and Bourjea, J. (in press) The spatial ecology of juvenile loggerhead turtles (Caretta caretta) in the Indian Ocean sheds light on the "lost years" mystery. Marine Biology, doi:10.1007/s002270142465z

Delgado de Molina, A., Floch, L., Rojo, V., Damiano, A., Aiz, J, Chassot, E, N'Gom, F., Chavance, P. and Tamegnon, A. (2013) Statistics of the european and associated purse seine and baitboat fleets, in the atlantic ocean. SCRS/2013/149. 
Delgado de Molina, A., Pallarés, P., Ariz, J. and Santana, J.C. (2000) Posibles efectos de la veda sobre objetos en la pesqueria espanola de cerco tropical. Collective Volume of Scientific Papers 51(2), 671-677.

Eckert, K.L., Wallace, B.P., Frazier, J.G., Eckert, S.A. and Pritchard, P.C.H. (2012) Synopsis of the Biological Data on the Leatherback Sea Turtle (Dermochelys coriacea). Biological Technical Publication BTP-R4015-2012, U.S. Fish and Wildlife Service, Washington, D.C.

Fennessy, S.T., Vincent, X., Budeba, Y., Mueni, E. M. and Gove, D. Z. (2008) An Update on Initiatives to Reduce Prawn Trawl Bycatch in the Western Indian Ocean. Western Indian Ocean Journal of Marine Science 7(2), 217-222.

Filmalter, J.D., Capello, M., Deneubourg, J.-L., Cowley, P.D. and Dagorn, L. (2013) Looking behind the curtain: quantifying massive shark mortality in fish aggregating devices. Frontiers in Ecology and the Environment 11(6), 291-296, doi:10.1890/130045

Fonteneau, A., Chassot, E. and Bodin, N. (2013) Global spatio-temporal patterns in tropical tuna purse seine fisheries on drifting fish aggregating devices (DFADs): Taking a historical perspective to inform current challenges. Aquatic Living Resources 26, 37-48.

Fonteneau, A., Pallares, P. and Pianet, R. (2000) A worldwide review of purse seine fisheries on FADs. In: Pêche thonière et dispositifs de concentration de poissons (proceedings of the 1st Symposium on Tuna fisheries and FADs, Martinique, October 1999). (eds J.Y. Le Gal, P. Cayré and M. Taquet). Actes Colloques-IFREMER 28, pp. 15-35.

Frazier, J.G. (1975) Marine turtles of the Western Indian Ocean. Oryx 13, 164-175.

Fréon, P. and Dagorn, L. (2000) Review of fish associative behaviour: toward a generalisation of the meeting point hypothesis. Reviews in Fish Biology and Fisheries 10, 183-207.

Gaos, A.R., Lewison, R.L., Wallace, B.P., Yañez, I.L., Liles, M.J., Nichols, W.J. Baquero, A., Hasbún, C.R., Vasquez, M., Urteaga, J. and Seminoff J.A. (2012). Spatial ecology of critically endangered hawksbill turtles Eretmochelys imbricata: implications for management and conservation. Marine Ecology Progress Series 450, 181-194.

Gooding, R.M. and Magnuson, J.J. (1967) Ecological significance of a drifting object to pelagic fishes. Pacific Science 21(4), 486-497.

Hall, M. A. (1999) Estimating the ecological impacts of fisheries: what data are needed to estimate bycatches? In: International Conference on Integrated Fisheries Monitoring (Proceedings of the International Conference on Integrated Fisheries Monitoring, . Ed. by C. P. Nolan Sydney, pp. 175-184

Hall, M.A. (1998) An ecological view of the tuna-dolphin problem: impacts and trade-offs. Reviews in Fish Biology and Fisheries 8, 1-34.

Hall, M.A. and Roman, M. (2013) Bycatch and non-tuna catch in the tropical tuna purse seine fisheries of the world. FAO Fisheries and Aquaculture Technical Paper No. 568. Rome, FAO. $249 \mathrm{pp}$.

Hall, M.A., Alversib, D.L. and Metuzals, K.I. (2000) Bycatch: problems and solutions. Marine Pollution Bulletin 41, 1-6.

Halpern, B.S., Walbridge, S., Selkoe, K.A., Kappel, C.V., Micheli, F., D'Agrosa, C., Bruno, J.F., Casey, K.S., Ebert, C., Fox, H.E., Fujita, R., Heinemann, D., Lenihan, H.S., Madin, 
E.M.P., Perry, M.T., Selig, E.R., Spalding, M., Steneck, R. and Watson R. (2008) A global map of human impact on marine ecosystems. Science 319, 948-952.

Hamanna, M., Grecha, A., Wolanskic, E. and Lambrechts, J. (2011) Modelling the fate of marine turtle hatchlings. Ecological Modelling 222, 1515-1521.

IOTC-SC15 (2012) Report of the Fifteenth Session of the IOTC Scientific Committee. Mahé, Seychelles, 10-15 December 2012. IOTC-2012-SC15-R[E], 288 pp.

Jackson, J.B.C., Kirby, M.X., Berger, W.H., Bjorndal, K.A., Botsford, L.W., Bourque, B.J., Bradbury, R.H., Cooke, R., Erlandson, J., Estes, J.A., Hughes, T.P., Kidwell, S., Lange, C.B., Lenihan, H.S., Pandolfi, J.M., Peterson, C.H., Steneck, R.S., Tegner M.J. and Warner, R.R. (2001) Historical overfishing and the recent collapse of coastal ecosystems. Science 293, 629-638

James, M.C., Eckert, S.A. and Myers, R.A. (2005) Migratory and reproductive movements of male leatherback turtles (Dermochelys coriacea). Marine Biology 145, 845-853.

Jenning, S. and Kaiser, M. (1998) The effects of fishing on marine ecosystems. Advances in Marine Biology 34, 203-302.

Lennert-Cody, C.E., Minami, M. and Hall, M. (2004) Incidental mortality of dolphins in the eastern Pacific Ocean purse-seine fishery: correlates and their spatial association. Journal of Cetacean Research and Management 6, 151-163.

Lewison, R.L., Crowder, L.B., Wallace, B. P., Moore, J. E., Cox, T., Zydelis, F., McDonald, S., DiMatteo, A., Dunn, D.C., Kot, C.Y., Bjorkland, R., Kelez, S., Soykan, C., Stewart, K.R., Sims, M., Boustany, A., Read, A.J., Halping, P., Nichols, W.J. and Safina, C. (2014) Global patterns of marine mammal, seabird, and sea turtle bycatch reveal taxa-specific and cumulative megafauna hotspots. Proceedings of the National Academy of Sciences 111 (14), 5271-5276.

Lewison, R.L., Freman, S.A. and Crowder, L.B. (2004) Quantifying the effects of fisheries on threatened species: the impact of pelagic longlines on loggerhead and leatherback sea turtles. Ecology Letters 7, 221-231

Limpus, C., Miller, J.D., Parmentier, C.J., C.J., Reiner, D., Mclachlan, N., Webb, R. (1992) Migration of green (Chelonia mydas) and loggerhead (Caretta caretta) turtles to and from east Australian rookeries. Wildlife Research 19, 347-358.

Lohmann, K.J., Putman, N.F. and Lohmann, C.M.F. (2012) The magnetic map of hatchling loggerhead sea turtles. Current Opinion in Neurobiology 22(2), 336-342.

Luschi, P. (2013) Long-distance animal migrations in the oceanic environment: orientation and navigation correlates. ISRN Zoology 2013, 1- 23.

Luschi, P., Benhamou, S., Girard, C., Ciccione, S., Roos, R., Sudre, J. and Benvenuti, S. (2007) Marine turtles use geomagnetic cues during open-sea homing. Current Biology 17, 126-133.

Luschi, P., Lutjeharms, J.R.E., Lambardi, R., Mencaccia, R., Hughes, G.R. and Hays, G.C. (2006) A review of migratory behaviour of sea turtles off south-eastern Africa. South African Journal of Science 102, 51-58.

Marquèz, R.M. (1990) Sea turtles of the world. FAO Species catalogue Roma, Italia. 
Miller, J.D. (1997) Reproduction in Sea Turtles. In: The biology of sea turtles (eds Lutz P.L .and Musick J.A.), Boca Raton, London, pp. 51- 81.

Monzón-Argüello, C., Lopez-Jurado, L.F., Rico, Marco, A., López, P., Hays, G.C. and Lee, P.L.M. (2010) Evidence from genetic and Lagrangian drifter data for transatlantic transport of small juvenile green turtles. Journal of Biogeography 37, 1752-1766.

Moore, J.E., Wallace B.P., Lewison R.L., Read, A.J., Bjorkland, R., McDonald, S.L., Crowder, L.B., Aruna, E., Ayissi, I., Espeut, P., Joynson-Hicks, C., Pilcher, N., Poonian, C.N.S, Solarin, B. and Kiszka, J. (2009) A review of marine mammal, sea turtle and seabird bycatch in USA fisheries and the role of policy in shaping management. Marine Policy 33, 435-451.

Nel, R., Punt, A.E. and Hughes, G.R. (2013) Are Coastal Protected Areas Always Effective in Achieving Population Recovery for Nesting Sea Turtles? Plos One 8(5): e63525.

NMFS. (2002) Atlantic highly migratory species; pelagic longline fishery; shark gillnet fishery; sea turtle and whale protection measures. Federal Register 67(131), 45393 - 45401.

Pauly, D., Watson, R. and Alder, J. (2005) Global trends in world fisheries: impacts on marine ecosystems and food security. Philosophical Transactions Royal Society B 360, 512.

Petersen, S.L., Honig, M.B., Nel, R., Ryan, P.G. and Underhill, L.G. (2009) Turtle bycatch in the pelagic longline fishery off Southern Africa. African Journal of Marine Science 31(1), 87 96.

Pianet R., Pallarés P. and Petit C. (2000) New sampling and data processing strategy for estimating the composition of catches by species and sizes in the European purse seine tropical tuna fisheries. IOTC-2000- WPDCS, $10 \mathrm{pp}$.

Proietti, M.C., Reisser, J.W., Kinas, Kerr, R., Monteiro, D.S., Marins, L.F. and Secchi, E.R. (2012) Green turtle Chelonia mydas mixed stocks in the western South Atlantic, as revealed by mtDNA haplotypes and drifter trajectories. Marine Ecology Progress Series 447, 195-209.

R Core Team (2013) R: A language and environment for statistical computing. F Foundation for Statistical Computing, Vienna, Austria. Version 3.0.2

Read, A.J. (2007) Do circle hooks reduce the mortality of sea turtles in pelagic longlines? A review of recent experiments. Biological Conservation 135, $155-169$.

Rochet, M.-J. and Trenkel, V.M. (2005) Factors for the variability of discards: assumptions and field evidence. Canadian Journal of Fisheries and Aquatic Sciences 62, 224-235.

Romanov, E.V. (2002) Bycatch in the tuna purse-seine fisheries of the western Indian Ocean. Fishery Bulletin 100, 90-105.

Sánchez, S., Murua, H., González, I., and Ruiz, J. (2007) Optimum sample number for estimating shark by-catch in the Spanish purse seiners in the Western Indian Ocean. IOTC2007-WPTT-26, 6 pp.

Shanker, K., Pandav, B. and Choudhury, B.C. (2003) An assessment of the olive ridley turtle (Lepidochelys olivacea) nesting population in Orissa, India. Biological Conservation 115, 149-160. 
Sims, M., Cox, T. and Lewison, R. (2008) Modeling spatial patterns in fisheries bycatch: improving bycatch maps to aid fisheries management. Ecological Applications 18, 649-661.

Thompson, S.K. (2002) Sampling (Wiley Series in Probability and Mathematical Statistics), Wiley, New-York.

Wallace, B.P., DiMatteo, A.D., Bolten, A.B.,Chaloupka, M.Y., Hutchinson, B., Abreu-Grobois, A., Mortimer, J.A., Seminoff, J.A., Amorocho, D., Bjorndal, K.A., Bourjea, J., Bowen, B.W,, Briseño Dueñas, R., Casale, P., Choudhury, B.C., Costa, A., Dutton, P.H., Fallabrino, A., Finkbeiner, E.M., Girard, A., Girondot, M., Hamann, M., Hurley, B.J., Lopez-Mendilaharsu, M., Marcovaldi, M.A., Musick, J.A., Nel, R., Pilcher, N.J., Troëng, S., Witherington, B. and Mast, R.B. (2011) Global Conservation Priorities for Marine Turtles. Plos One 6(9): e24510.

Wallace, B.P., Lewison, R.L., McDonald, S.L., McDonald, R.K., Kot, C.Y., Kelez, S., Bjorkland, R.K., Finkbeiner, E.M., Helmbrecht, S. and Crowder, L.B. (2010) Global patterns of marine turtle bycatch. Conservation Letters 3, 131-142.

Wallace, P.W., Heppell, S.S., Lewison R.L., Kelez, S. and Crowder, L.B. (2008) Impacts of fisheries bycatch on loggerhead urtles worldwide inferred from reproductive value analyses. Journal of Applied Ecology 45, 1076-1085

WCPFC. (2009) FAD management and monitoring. Western and Central Pacific Fisheries Commission, Technical and Central Pacific Fisheries Commission, Technical and Compliance Committee, Fifth regular session, WCPFC-TCC5-2009/22.

Wilcox, C., Hardesty, B.D.,Sharples, R., Griffin, D.A., Lawson, T.J. and Gunn, R. (2012) Ghostnet impacts on globally threatened turtles, a spatial risk analysis for northern Australia. Conservation Letters 1, 1-8.

Witherington, B, Hirama, S. and Hardy, R. (2012) Young sea turtles of the pelagic Sargassum-dominated drift community: habitat use, population density, and threats. Marine ecology Progress Series 463, 1-22.

Worton, B.J. (1989) Kernel Methods for Estimating the Utilization Distribution in Home-Range Studies. Ecology 70, 164-168.

Worton, B.J. (1995) Using Monte Carlo Simulation to Evaluate Kernel-Based Home Range Estimators. The Journal of Wildlife Management 59(4), 794-800. 
Table 1 Periods where French and Spanish observer programs were actives and from which database the data were extracted for this study.

\begin{tabular}{|c|c|c|c|c|}
\hline \multirow{2}{*}{$\begin{array}{l}\text { Observer } \\
\text { Programs }\end{array}$} & \multicolumn{2}{|r|}{ France } & \multicolumn{2}{|r|}{ Spain } \\
\hline & Period & Institute involved & Period & Institute involved \\
\hline Associated Fauna & $\begin{array}{l}1995- \\
1996\end{array}$ & IRD* & 1995 & IEO \\
\hline $\begin{array}{c}\text { ICCAT }^{* *} \text { Bigeye } \\
\text { Year }\end{array}$ & $\begin{array}{l}1998- \\
1999\end{array}$ & IRD & 1997-1999 & IEO \\
\hline ICCAT Moratorium & $\begin{array}{l}1997- \\
2005\end{array}$ & IRD & & IEO \\
\hline EU DCR ${ }^{* * *}$ & $\begin{array}{l}2005- \\
2011\end{array}$ & IRD & $2003-2011$ & $\mathrm{AZTI}^{5 *}$ and $\mathrm{IEO}^{6 *}$ \\
\hline $\mathrm{TAAF}^{4 *}$ & $\begin{array}{l}2009- \\
2011\end{array}$ & TAAF and IRD & - & - \\
\hline \multicolumn{5}{|c|}{$\begin{array}{l}\text { * Institut de Recherche pour le Développement } \\
\text { ** The International Commission for the Conservation of Atlantic Tunas } \\
\text { *** European Union Data Collection Framework } \\
\text { 4* Terres Australes et Antarctiques Françaises }\end{array}$} \\
\hline
\end{tabular}


Table 2: Number of purse-seine sets, observed sets, observed floating objects and observed marine turtles bycatch per year for the French and Spanish Purse seine fleet in the Atlantic and Indian oceans. DFAD: Drifting Fish Aggregating Device; FSC: Free Swimming School; SD: Standard Deviation; nb: number.

\begin{tabular}{|c|c|c|c|c|c|c|c|c|c|c|c|c|c|c|}
\hline \multirow[b]{3}{*}{ Year } & \multicolumn{12}{|c|}{ Fishing sets } & \multicolumn{2}{|c|}{ Object } \\
\hline & \multicolumn{5}{|c|}{ DFAD } & \multicolumn{5}{|c|}{ FSC } & \multicolumn{2}{|c|}{ Unkown } & \multirow[b]{2}{*}{$\begin{array}{l}\text { Nb object } \\
\text { observed }\end{array}$} & \multirow{2}{*}{$\begin{array}{c}\text { nb of marine } \\
\text { turtle } \\
\text { bycatch }\end{array}$} \\
\hline & $\begin{array}{l}\text { Total } \\
\text { sets }\end{array}$ & $\begin{array}{l}\text { Observed } \\
\text { sets }\end{array}$ & Coverage (\%) & $\begin{array}{l}\text { nb of marine } \\
\text { turtle bycatch }\end{array}$ & $\begin{array}{l}\text { Annual bycatch } \\
\text { rate }\end{array}$ & $\begin{array}{c}\text { Total } \\
\text { sets }\end{array}$ & $\begin{array}{l}\text { Observed } \\
\text { sets }\end{array}$ & Coverage (\%) & $\begin{array}{l}\text { nb of marine } \\
\text { turtle bycatch }\end{array}$ & $\begin{array}{l}\text { Annual bycatch } \\
\text { rate }\end{array}$ & $\begin{array}{l}\text { Total } \\
\text { sets }\end{array}$ & Observed sets & & \\
\hline 1995 & 3690 & 71 & 1.9 & 5 & 0.070 & 4754 & 249 & 5.2 & 15 & 0.060 & 156 & 0 & & \\
\hline 1996 & 3466 & 1 & 0 & & 0.000 & 4330 & 39 & 0.9 & 1 & 0.026 & 38 & 0 & & \\
\hline 1997 & 2412 & 259 & 10.7 & 14 & 0.054 & 3717 & 774 & 20.8 & 28 & 0.036 & 109 & 0 & & \\
\hline 1998 & 2153 & 715 & 33.2 & 54 & 0.076 & 4371 & 1585 & 36.3 & 43 & 0.027 & 326 & 0 & & \\
\hline 1999 & 1782 & 404 & 22.7 & 26 & 0.064 & 3576 & 737 & 20.6 & 18 & 0.024 & 237 & 0 & & \\
\hline 2000 & 2144 & 104 & 4.9 & 1 & 0.010 & 3686 & 237 & 6.4 & 9 & 0.038 & 196 & 0 & & \\
\hline 2001 & 2055 & 151 & 7.3 & 1 & 0.007 & 3698 & 397 & 10.7 & 4 & 0.010 & 191 & 0 & & \\
\hline 2002 & 1643 & 136 & 8.3 & 2 & 0.015 & 3103 & 220 & 7.1 & 3 & 0.014 & 82 & 0 & & \\
\hline 2003 & 1910 & 198 & 10.4 & 13 & 0.066 & 4148 & 357 & 8.6 & 16 & 0.045 & 57 & 0 & 121 & 0 \\
\hline 2004 & 1921 & 184 & 9.6 & 3 & 0.016 & 2562 & 233 & 9.1 & 3 & 0.013 & 91 & 0 & 121 & 2 \\
\hline 2005 & 1429 & 86 & 6 & 5 & 0.058 & 1976 & 112 & 5.7 & 4 & 0.036 & 28 & 0 & 162 & 1 \\
\hline 2006 & 1231 & 31 & 2.5 & 1 & 0.032 & 1505 & 66 & 4.4 & 4 & 0.061 & 12 & 0 & 168 & 0 \\
\hline 2007 & 1449 & 82 & 5.7 & 4 & 0.049 & 1519 & 107 & 7 & 7 & 0.065 & 8 & 0 & 341 & 13 \\
\hline 2008 & 2030 & 177 & 8.7 & 7 & 0.040 & 2063 & 217 & 10.5 & 9 & 0.041 & 8 & 0 & 504 & 15 \\
\hline 2009 & 2710 & 163 & 6 & 8 & 0.049 & 2994 & 261 & 8.7 & 12 & 0.046 & 2 & 0 & 583 & 22 \\
\hline 2010 & 3702 & 326 & 8.8 & 34 & 0.104 & 2912 & 432 & 14.8 & 23 & 0.053 & 12 & 0 & 1421 & 32 \\
\hline 2011 & 3280 & 295 & 9.0 & 23 & 0.078 & 1594 & 362 & 22.7 & 15 & 0.041 & 0 & & 1354 & 31 \\
\hline 1995-2011 & 39007 & 3383 & $9.2(\mathrm{SD}=7.9)$ & 201 & $0.046(\mathrm{SD}=0.029)$ & 52508 & 6023 & $11.7(\mathrm{SD}=8.8)$ & 214 & $0.037(S D=0.017)$ & 1553 & 0 & 4775 & 116 \\
\hline $\begin{array}{l}\text { average per } \\
\text { observation }\end{array}$ & & & & 0.059 & & & & & 0.036 & & & & & \\
\hline 1995 & 2275 & 65 & 2.9 & 8 & 0.123 & 2247 & 365 & 16.2 & 16 & 0.044 & & & & \\
\hline 1996 & 1998 & & & & & 1953 & & & & & & & & \\
\hline 1997 & 2247 & & & & & 1364 & & & & & & & & \\
\hline 1998 & 1998 & 486 & 24.3 & 24 & 0.049 & 1332 & 680 & 51.1 & 4 & 0.006 & & & & \\
\hline 1999 & 1617 & & & & & 1622 & & & & & & & & \\
\hline 2000 & 5076 & & & & & 3669 & & & & & 189 & 0 & & \\
\hline 2001 & 4281 & & & & & 4278 & & & & & 176 & 0 & & \\
\hline 2002 & 5103 & & & & & 3107 & & & & & 108 & 0 & & \\
\hline 2003 & 3883 & 108 & 2.8 & 6 & 0.056 & 4136 & 64 & 1.5 & 1 & 0.016 & 149 & 0 & 331 & 4 \\
\hline 2004 & 3449 & 146 & 4.2 & 8 & 0.055 & 4927 & 94 & 1.9 & & 0.000 & 127 & 0 & 864 & 3 \\
\hline 2005 & 4443 & 166 & 3.7 & 5 & 0.030 & 5635 & 298 & 5.3 & 3 & 0.010 & 176 & 0 & 596 & 3 \\
\hline 2006 & 5295 & 294 & 5.6 & 21 & 0.071 & 5635 & 248 & 4.4 & & 0.000 & 49 & 0 & 790 & 28 \\
\hline 2007 & 5114 & 411 & 8 & 41 & 0.100 & 4676 & 464 & 9.9 & 5 & 0.011 & 3 & 0 & 1822 & 89 \\
\hline 2008 & 4748 & 442 & 9.3 & 18 & 0.041 & 4236 & 256 & 6 & 1 & 0.004 & 11 & 0 & 1434 & 59 \\
\hline 2009 & 4940 & 461 & 9.3 & 6 & 0.013 & 1989 & 189 & 9.5 & & 0.000 & 4 & 0 & 1732 & 21 \\
\hline 2010 & 5267 & 401 & 7.6 & 9 & 0.022 & 1725 & 182 & 10.6 & 1 & 0.005 & 8 & 0 & 1071 & 15 \\
\hline 2011 & 5320 & 152 & 2.9 & 2 & 0.013 & 2050 & 173 & 8.4 & 3 & 0.017 & 0 & & 708 & 16 \\
\hline 1995-2011 & 67054 & 3132 & 7.8. $(S D=6.2)$ & 148 & $0.052(\mathrm{SD}=0.035)$ & 54581 & 3013 & $11.3(\mathrm{SD}=13.9)$ & 34 & $0.01(\mathrm{SD}=0.013)$ & 1000 & 0 & 9348 & 238 \\
\hline $\begin{array}{l}\text { average per } \\
\text { observation }\end{array}$ & & & & 0.047 & & & & & 0.011 & & & & & 0.025 \\
\hline
\end{tabular}


Table 3: Total number of marine turtle bycatch in observed purse-seine sets of French and Spanish Purse seine fleet in the Atlantic and Indian oceans. Numbers are provided by ocean, species, fate (alive/dead) and percentage of turtles released alive and dead by fishing mode. DFAD: Drifting Fish Aggregating Device; FSC: Free Swimming School.

\begin{tabular}{|c|c|c|c|c|c|c|c|c|c|c|c|}
\hline \multicolumn{3}{|c|}{ SPECIES } & \multicolumn{4}{|c|}{ Atlantic Ocean } & \multicolumn{4}{|c|}{ Indian Ocean } & \\
\hline Scientific name & Common name & Code & Alive & Dead & Unknown & Total & Alive & Dead & Unknown & Total & \\
\hline Caretta caretta & Loggerhead & $\mathrm{CCC}$ & 67 & 3 & 3 & 73 & 13 & 3 & 3 & 19 & 92 \\
\hline Chelonia mydas & Green turtle & CMM & 36 & & 4 & 40 & 24 & 2 & 6 & 32 & 72 \\
\hline Dermochelys coriacea & Leatherback & DCC & 60 & 4 & 3 & 67 & 2 & & & 2 & 69 \\
\hline Eretmochelys imbricata & Hawksbill & EIM & 12 & 2 & & 14 & 32 & 2 & 3 & 37 & 51 \\
\hline Lepidochelys kempii & Kemp' turtle & LKE & 35 & 2 & 1 & 38 & & & & & 38 \\
\hline Lepidochelys olivacea & Olive ridley & LCE & 73 & 1 & 2 & 76 & 47 & 4 & 7 & 58 & 134 \\
\hline \multirow[t]{7}{*}{ Unidentified turtles } & - & - & 93 & 9 & 5 & 107 & 22 & 9 & 3 & 34 & 141 \\
\hline & & Total & 376 & 21 & 18 & 415 & 140 & 20 & 22 & 182 & \\
\hline & Occu & rence (\%) & $91 \%$ & $5 \%$ & $4 \%$ & & $77 \%$ & $11 \%$ & $12 \%$ & & \\
\hline & & on DFAD & 185 & 7 & 9 & 201 & 113 & 16 & 19 & 148 & \\
\hline & Occu & rence (\%) & $92.0 \%$ & $3.5 \%$ & $4.5 \%$ & $48.4 \%$ & $76.4 \%$ & $10.8 \%$ & $12.8 \%$ & $81.3 \%$ & 597 \\
\hline & & on FSC & 191 & 14 & 9 & 214 & 27 & 4 & 3 & 34 & \\
\hline & Occu & rence (\%) & $89.3 \%$ & $6.5 \%$ & $4.2 \%$ & $51.6 \%$ & $79.4 \%$ & $11.8 \%$ & $8.8 \%$ & $18.7 \%$ & \\
\hline
\end{tabular}

Table 4: Total number of marine turtle bycatch in observed purse-seine sets of French and Spanish Purse seine fleet in the Atlantic and Indian oceans. Numbers are provided by ocean, species and life stage (adult/juvenile) and percentage of identified adult and juvenile turtles by ocean.

\begin{tabular}{|c|c|c|c|c|c|c|c|c|c|}
\hline \multirow{2}{*}{ Species } & \multicolumn{4}{|c|}{ Atlantic Ocean } & \multicolumn{4}{|c|}{ Indian Ocean } & \multirow{2}{*}{ Total } \\
\hline & Adult & Juvenile & Unknown & Total & Adult & Juvenile & Unknown & Total & \\
\hline Caretta caretta & 21 & 7 & & 28 & 1 & 9 & 2 & 12 & 40 \\
\hline Chelonia mydas & 5 & 18 & & 23 & 3 & 18 & 1 & 22 & 45 \\
\hline Dermochelys coriacea & 47 & 16 & & 63 & & & & & 63 \\
\hline Eretmochelys imbricata & 2 & 6 & & 8 & & 31 & & 31 & 39 \\
\hline Lepidochelys kempii & 34 & 9 & & 43 & & & & & 43 \\
\hline Lepidochelys olivacea & 48 & 16 & & 64 & 17 & 27 & & 44 & 108 \\
\hline Unidentified turtles & 2 & 2 & 2 & 6 & & 2 & 6 & 8 & 14 \\
\hline Total & 159 & 74 & 2 & 235 & 21 & 87 & 9 & 117 & 352 \\
\hline Occurrence (\%) & $68 \%$ & $31 \%$ & $1 \%$ & & $18 \%$ & $74 \%$ & $8 \%$ & & \\
\hline
\end{tabular}

Table 5: Total number of marine turtles observed at floating objects by species and fate (alive/dead) in the Atlantic and Indian oceans.

\begin{tabular}{|c|c|c|c|c|c|c|c|c|c|}
\hline \multirow[b]{2}{*}{ Species } & \multicolumn{4}{|c|}{ Atlantic Ocean } & \multicolumn{4}{|c|}{ Indian Ocean } & \multirow[b]{2}{*}{ Total } \\
\hline & $\begin{array}{c}\text { Entangled } \\
\text { alive }\end{array}$ & $\begin{array}{c}\text { Entangled } \\
\text { dead }\end{array}$ & Free & Total & $\begin{array}{c}\text { Entangled } \\
\text { alive }\end{array}$ & $\begin{array}{c}\text { Entangled } \\
\text { dead }\end{array}$ & Free & Total & \\
\hline Caretta caretta & 6 & & 1 & 7 & 10 & 6 & 2 & 18 & 25 \\
\hline Chelonia mydas & 2 & & 4 & 6 & 12 & 10 & 15 & 37 & 43 \\
\hline Dermochelys coriacea & 4 & & 4 & 8 & 2 & & 4 & 6 & 14 \\
\hline Eretmochelys imbricata & 4 & & 2 & 6 & 17 & 10 & 13 & 40 & 46 \\
\hline Lepidochelys kempii & 2 & & 10 & 12 & & & & & 12 \\
\hline Lepidochelys olivacea & 26 & 1 & 14 & 41 & 34 & 21 & 19 & 74 & 115 \\
\hline Unidentified turtles & 14 & 7 & 15 & 36 & 34 & 18 & 11 & 63 & 95 \\
\hline Total & 58 & 8 & 50 & 116 & 109 & 65 & 64 & 238 & 350 \\
\hline Occurrence (\%) & $50 \%$ & $7 \%$ & $43 \%$ & & $46 \%$ & $27 \%$ & $27 \%$ & & \\
\hline
\end{tabular}


Table 6: Estimation of the total number of marine turtle bycaugth in the French and Spanish Purse seine fleet in the Atlantic and Indian oceans from 1995 to 2010. DFAD: Drifting Fish Aggregating Device; FSC: Free Swimming School; SD: Standard Deviation.

\begin{tabular}{|c|c|c|c|c|c|c|}
\hline \multicolumn{2}{|c|}{ Number of by-caught } & \multicolumn{2}{|c|}{ Total number of fishing sets } & \multirow{2}{*}{ Survival rate } & \multirow{2}{*}{$\begin{array}{c}\text { Total estimation } \\
\text { of by-caught }\end{array}$} & \multirow{2}{*}{$\begin{array}{c}\text { Total estimation } \\
\text { of dead turtle }\end{array}$} \\
\hline DFAD & FSC & DFAD & FSC & & & \\
\hline 0.07 & 0.06 & 3690 & 4754 & 0.89 & 544 & 57 \\
\hline 0.00 & 0.03 & 3466 & 4330 & 1.00 & 113 & 0 \\
\hline 0.05 & 0.04 & 2412 & 3717 & 0.72 & 264 & 74 \\
\hline 0.08 & 0.03 & 2153 & 4371 & 0.99 & 282 & 3 \\
\hline 0.06 & 0.02 & 1782 & 3576 & 1.00 & 200 & 0 \\
\hline 0.01 & 0.04 & 2144 & 3686 & 0.90 & 162 & 16 \\
\hline 0.01 & 0.01 & 2055 & 3698 & 1.00 & 51 & 0 \\
\hline 0.02 & 0.01 & 1643 & 3103 & 1.00 & 68 & 0 \\
\hline 0.07 & 0.05 & 1910 & 4148 & 0.93 & 313 & 22 \\
\hline 0.02 & 0.01 & 1921 & 2562 & 0.75 & 64 & 16 \\
\hline 0.06 & 0.04 & 1429 & 1976 & 1.00 & 154 & 0 \\
\hline 0.03 & 0.06 & 1231 & 1505 & 1.00 & 131 & 0 \\
\hline 0.05 & 0.07 & 1449 & 1519 & 1.00 & 170 & 0 \\
\hline 0.04 & 0.04 & 2030 & 2063 & 1.00 & 166 & 0 \\
\hline 0.05 & 0.05 & 2710 & 2994 & 0.94 & 271 & 15 \\
\hline 0.10 & 0.05 & 3702 & 2912 & 1.00 & 539 & 0 \\
\hline \multirow[t]{4}{*}{0.09} & 0.04 & 3280 & 1594 & 0.95 & 359 & 18 \\
\hline & & & Sum & & 3849 & 222 \\
\hline & & & Mean & 0.95 & 226 & 13 \\
\hline & & & SD & 0.09 & 148 & 22 \\
\hline \multirow[t]{3}{*}{0.12} & 0.04 & 2275 & 2247 & 0.79 & 379 & 79 \\
\hline & & 1998 & 1953 & & & \\
\hline & & 2247 & 1364 & & & \\
\hline \multirow[t]{5}{*}{0.05} & 0.01 & 1998 & 1332 & 0.86 & 106 & 15 \\
\hline & & 1617 & 1622 & & & \\
\hline & & 5076 & 3669 & & & \\
\hline & & 4281 & 4278 & & & \\
\hline & & 5103 & 3107 & & & \\
\hline 0.06 & 0.02 & 3883 & 4136 & 0.60 & 284 & 113 \\
\hline 0.06 & 0.00 & 3449 & 4927 & 1.00 & 190 & 0 \\
\hline 0.03 & 0.01 & 4443 & 5635 & 0.67 & 190 & 63 \\
\hline 0.07 & 0.00 & 5295 & 5635 & 0.86 & 376 & 54 \\
\hline 0.10 & 0.01 & 5114 & 4676 & 0.92 & 563 & 47 \\
\hline 0.04 & 0.00 & 4748 & 4236 & 1.00 & 212 & 0 \\
\hline 0.01 & 0.00 & 4940 & 1989 & 1.00 & 64 & 0 \\
\hline 0.02 & 0.01 & 5267 & 1725 & 1.00 & 124 & 0 \\
\hline \multirow[t]{4}{*}{0.01} & 0.02 & 5320 & 2050 & 0.80 & 94 & 19 \\
\hline & & & Sum & & 2581 & 390 \\
\hline & & & Mean & 0.86 & 235 & 35 \\
\hline & & & SD & 0.14 & 153 & 39 \\
\hline
\end{tabular}




\section{Figures}

Figure 1: Total number of purse-seine sets on FSC (A), observed sets on FSC (B) and number of marine turtles bycatch per observed set on FSC (C) per statistical square of $1^{\circ}$ in the French and Spanish Purse seine fleet from 1995-2011 in the Atlantic and Indian oceans

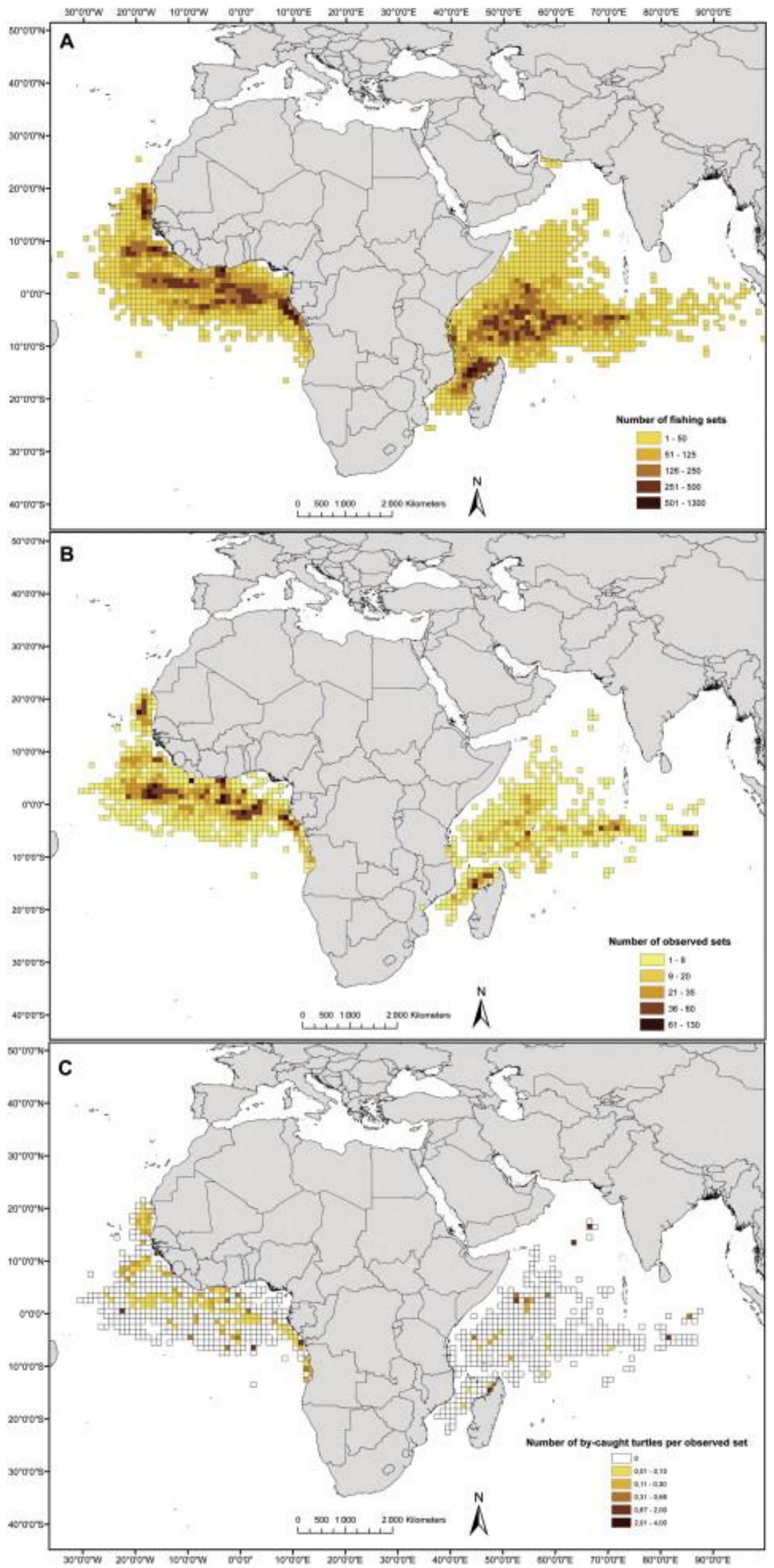


Figure 2: Total number of purse-seine sets on DFADs (A), observed sets on DFADs (B) and number of marine turtle bycatch per observed set on DFADs (C) per statistical square of $1^{\circ}$ in the French and Spanish Purse seine fleet from 1995-2011 in the Atlantic and Indian oceans

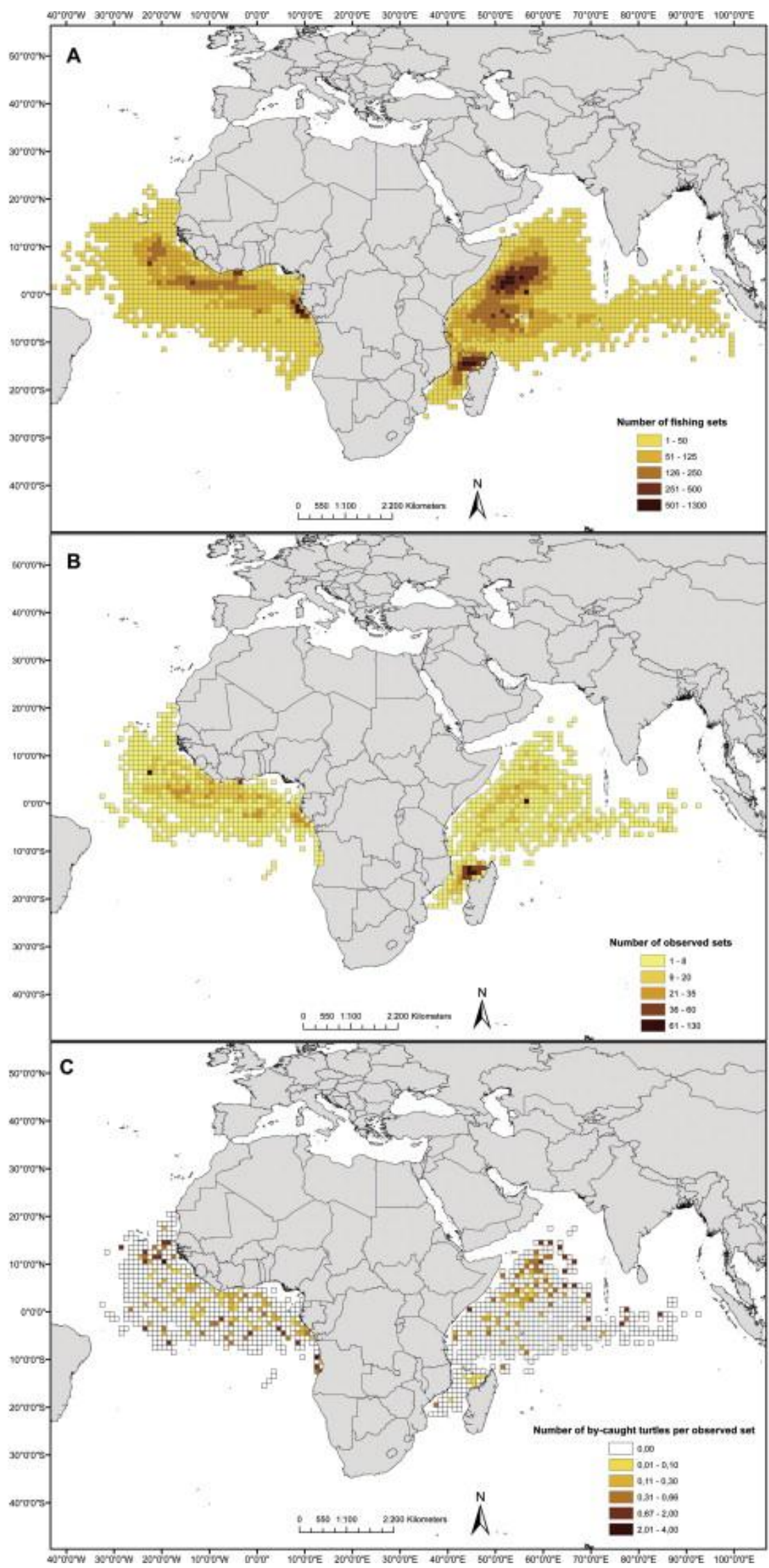


Figure 3: Total number of object observed $(A)$ and number of observed marine turtles per object observation (B) per statistical square of $1^{\circ}$ in the French and Spanish Purse seine fleet from 2003-2011 in the Atlantic and Indian Oceans

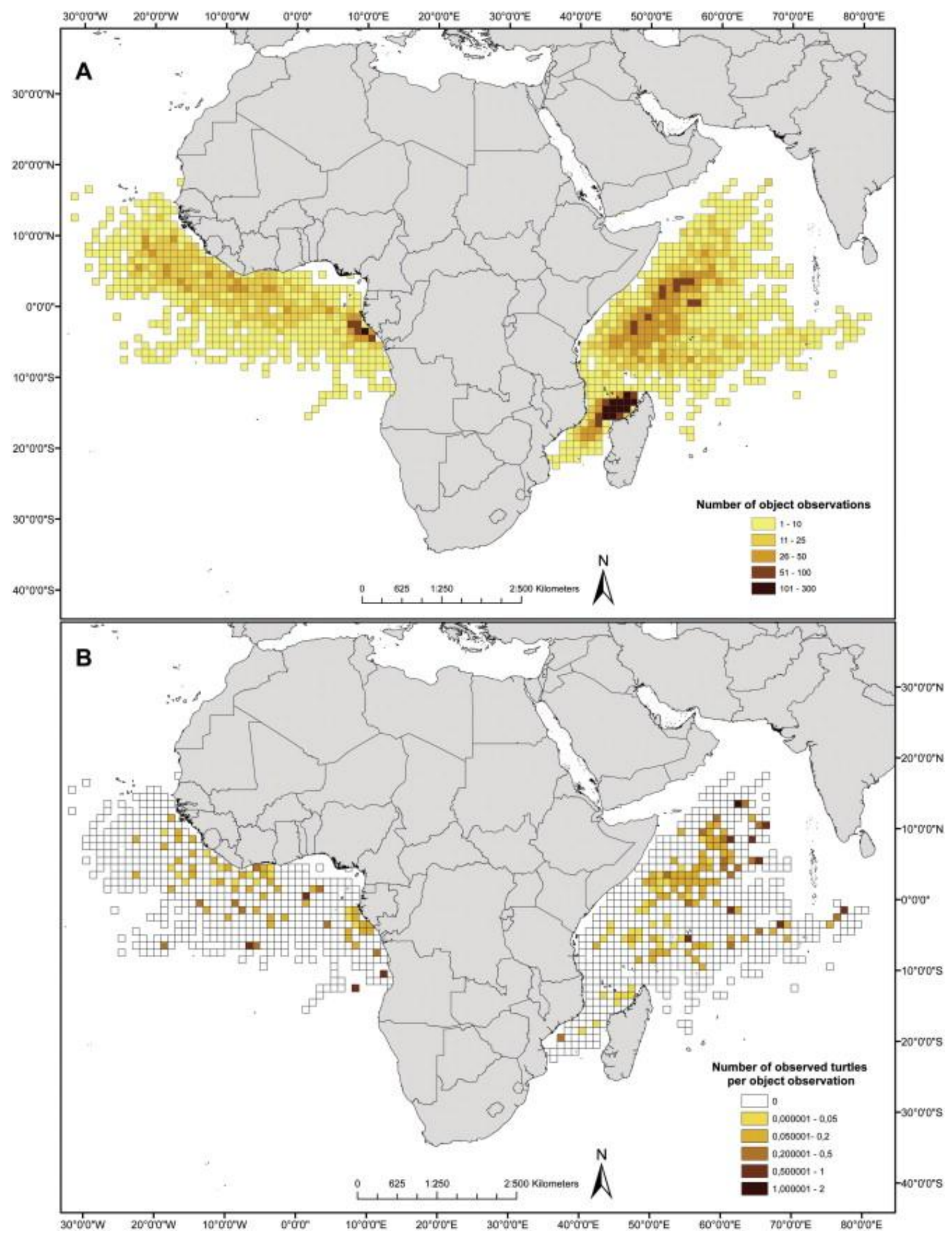


Figure 4 (COLOR PRINTING): Distribution of observed marine turtles bycatch by species in the French and Spanish Purse seine fishing on FADs and FSCs sets in the Atlantic (A) and Indian (B) Oceans for the period 1995-2011. Observed marine turtles on floating devices during the study period 2003-2011 are also presented for the Atlantic (C) and Indian (C) oceans.

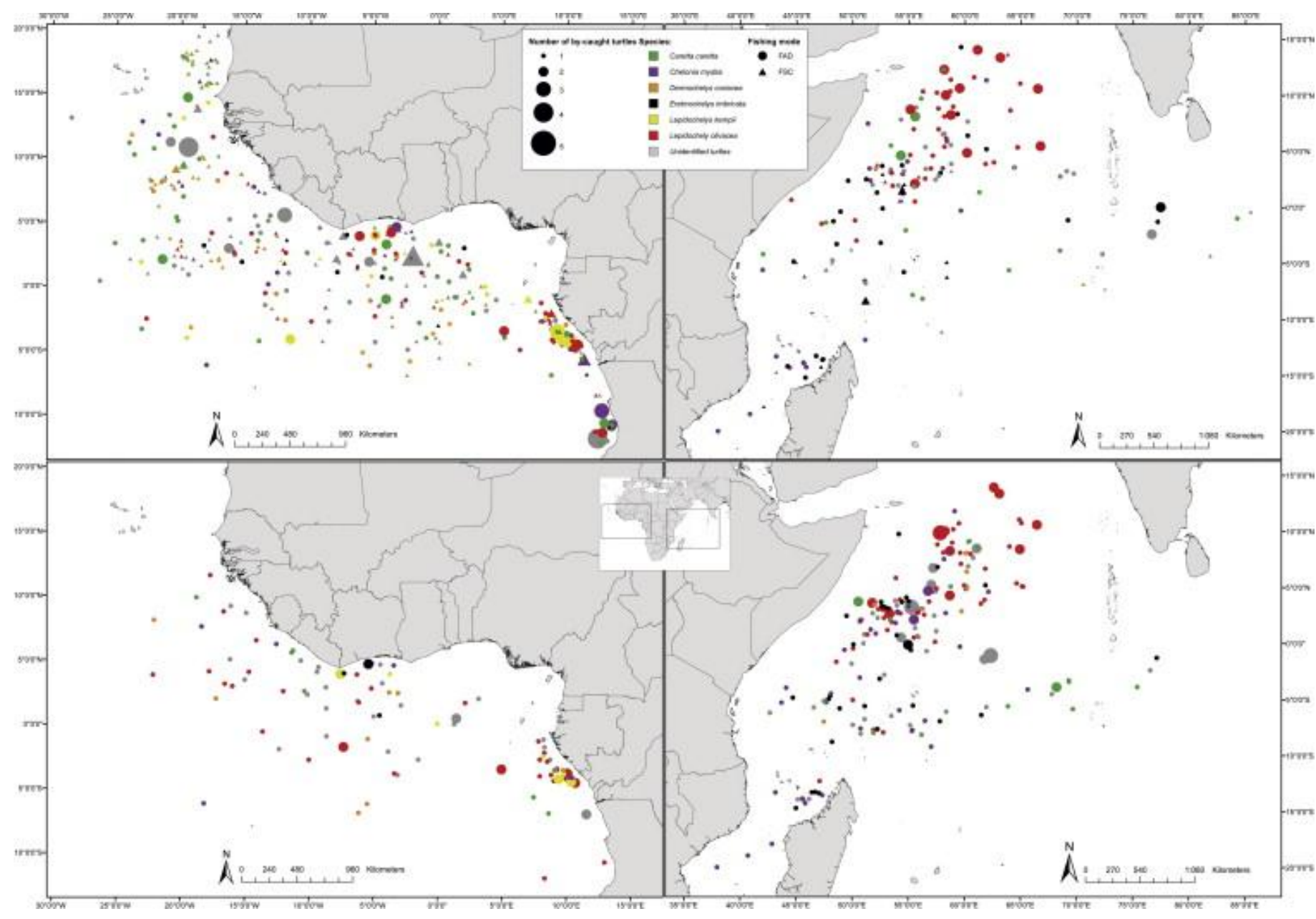


Figure 5 (COLOR PRINTING): Estimated Utilization Distributions with the kernel method using marine turtle geographical interactions with European purse-seine. Data used are from observed purse-seine sets for the period 1995-2011 (A) and from observed floating devices during the study period 2003-2011 (B). Both (A) and (B) also show latitudinal and longitudinal barycentres and standard deviations of each species captured by European purse-seine fleet during observed sets (A) and observed on floating objects (B). (A) CCC: Caretta caretta (Atlantic Ocean $\mathrm{N}=73$; Indian Ocean $\mathrm{N}=19$ ), CMM: Chelonia mydas (Atlantic Ocean $\mathrm{N}=40$; Indian Ocean N=32), DCC: Dermochelys coriacea (Atlantic Ocean N=67; Indian Ocean N=2), EIM: Eretmochelys imbricata (Atlantic Ocean N=14; Indian Ocean N=37), LKE: Lepidochelys kempii (Atlantic Ocean N=37) and LOL: Lepidochelys olivacea (Atlantic Ocean N=76; Indian Ocean $\mathrm{N}=58$ ). (B) CCC (Atlantic Ocean $\mathrm{N}=7$; Indian Ocean $\mathrm{N}=18$ ), CMM (Atlantic Ocean $\mathrm{N}=6$; Indian Ocean $\mathrm{N}=37$ ), DCC (Atlantic Ocean $\mathrm{N}=8$; Indian Ocean $\mathrm{N}=6$ ), EIM (Atlantic Ocean $\mathrm{N}=6$; Indian Ocean $\mathrm{N}=40$ ), LKE (Atlantic Ocean $\mathrm{N}=10$ ) and LOL (Atlantic Ocean $\mathrm{N}=41$; Indian Ocean $\mathrm{N}=74$ ).

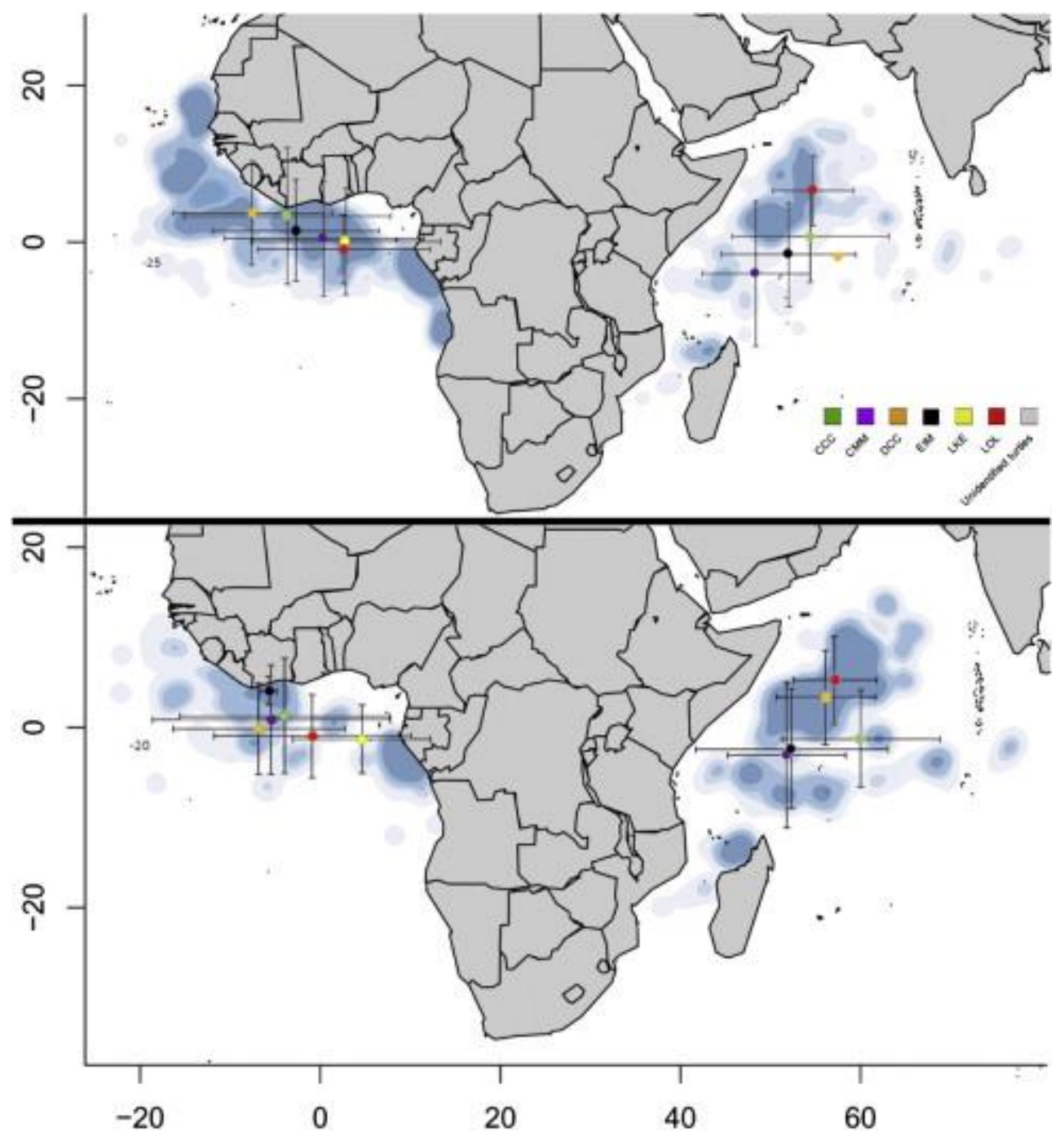


Figure A1: Total fishing effort (in number of fishing sets) of purse-seine on DFADs for quarter 1 (a), quarter 2 (b), quarter 3 (c), quarter 1 (4), per statistical square of $1^{\circ}$ in the French and Spanish Purse seine fleet from 1995-2011 in the Atlantic and Indian oceans

Figure A2: Total fishing effort (in number of fishing sets) of purse-seine on FSCs for quarter 1 (a), quarter 2 (b), quarter 3 (c), quarter 1 (4), per statistical square of $1^{\circ}$ in the French and Spanish Purse seine fleet from 1995-2011 in the Atlantic and Indian oceans

Figure A3: Total number of purse-seine sets on DFADs for quarter 1 (a), quarter 2 (b), quarter 3 (c), quarter 1 (4), per statistical square of $1^{\circ}$ in the French and Spanish Purse seine fleet from 1995-2011 in the Atlantic and Indian oceans

Figure A4: Total number of purse-seine sets on FSCs for quarter 1 (a), quarter 2 (b), quarter 3 (c), quarter 1 (d), per statistical square of $1^{\circ}$ in the French and Spanish Purse seine fleet from 1995-2011 in the Atlantic and Indian oceans

Figure A5: Number of marine turtles by-caught per observed purse seine set on DFADs for quarter 1 (a), quarter 2 (b), quarter 3 (c), quarter 1 (4), per statistical square of $1^{\circ}$ from 1995 to 2011 in the Atlantic and Indian oceans

Figure A6: Number of marine turtles by-caught per observed purse seine set on FSCs for quarter 1 (a), quarter 2 (b), quarter 3 (c), quarter 1 (4), per statistical square of $1^{\circ}$ from 1995 to 2011 in the Atlantic and Indian oceans

Figure A7: Number of marine turtles by species by-caught in the Atlantic Ocean by European Union purseseiners during observed sets on FADs and FSCs over the study period 1995-2011; quarter 1 (a), quarter 2 (b), quarter 3 (c) and quarter 4 (d)

Figure A8: Number of marine turtles by species by-caught in the Indian Ocean by European Union purseseiners during observed sets on FADs and FSCs over the study period 1995-2011; quarter 1 (a), quarter 2 (b), quarter 3 (c) and quarter 4 (d) 

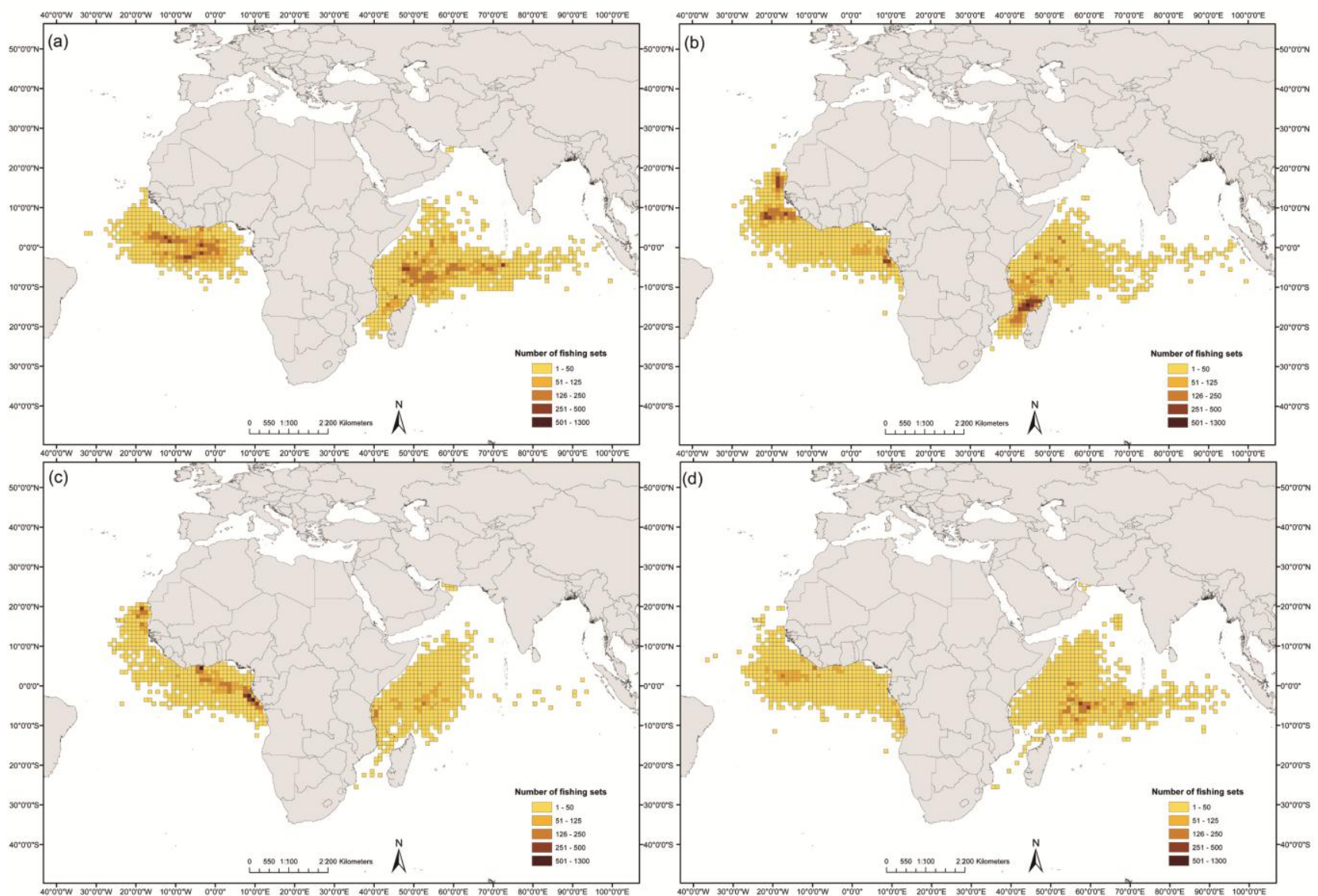

Figure A1
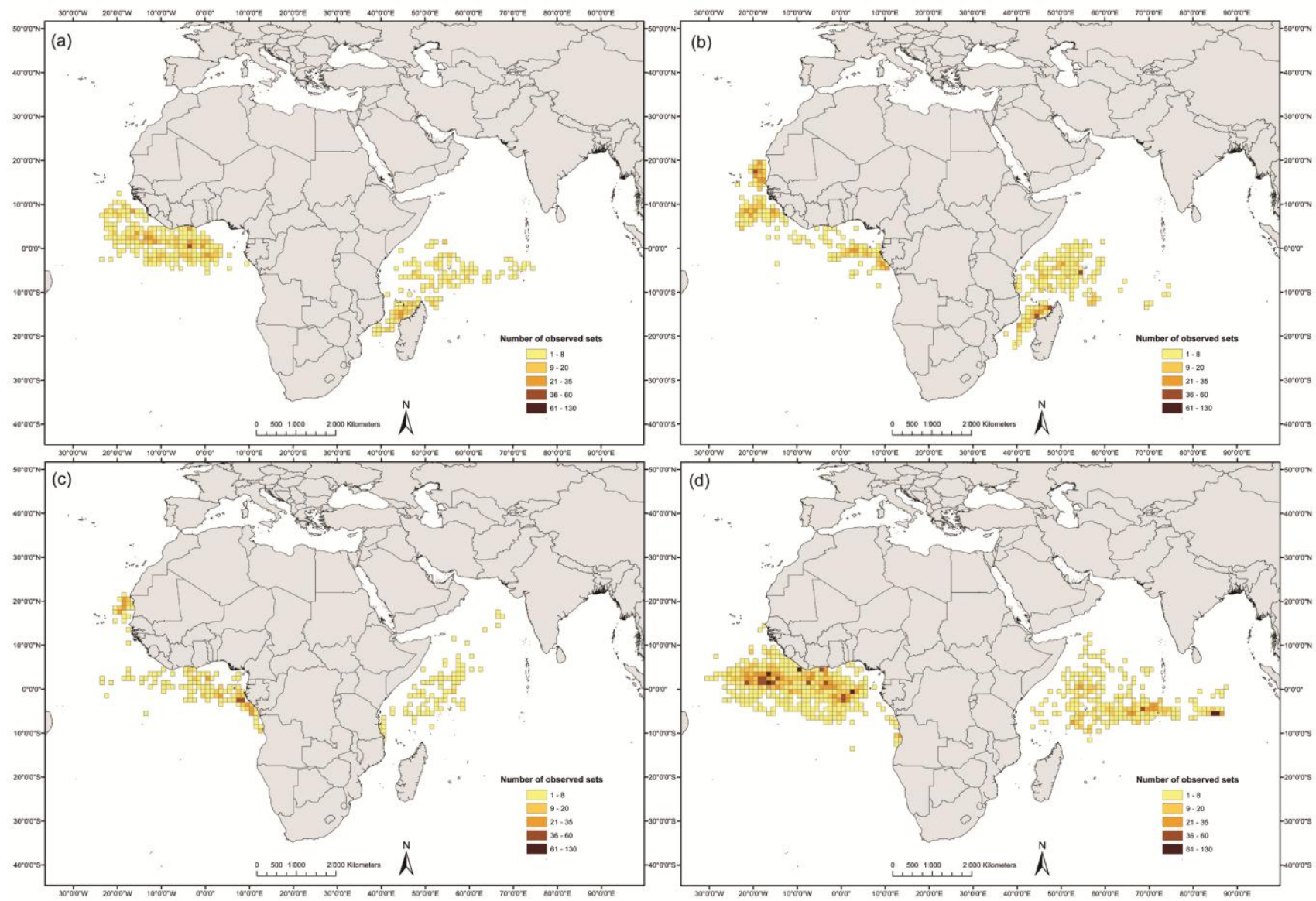

Figure $A 2$ 


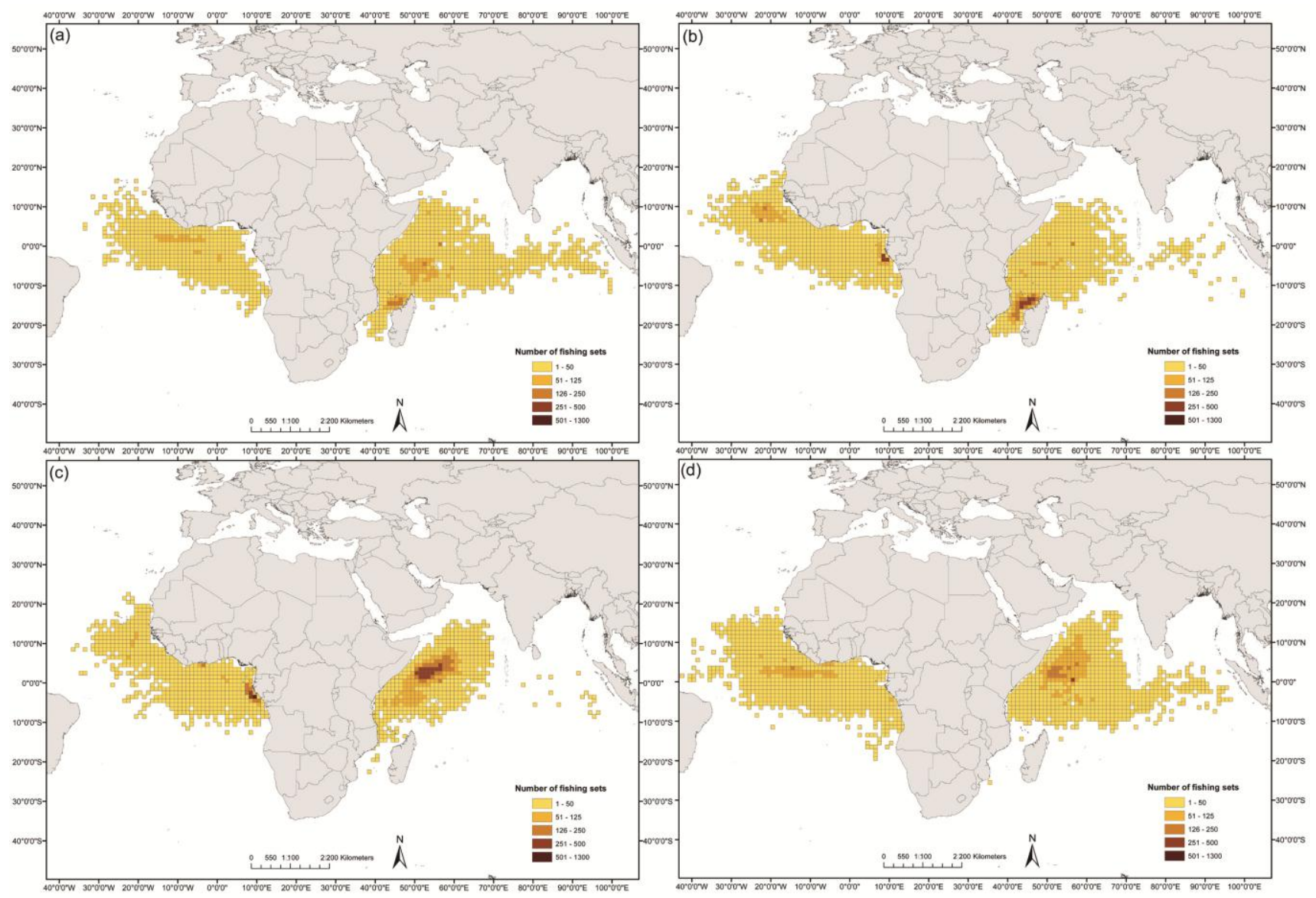

Figure A3
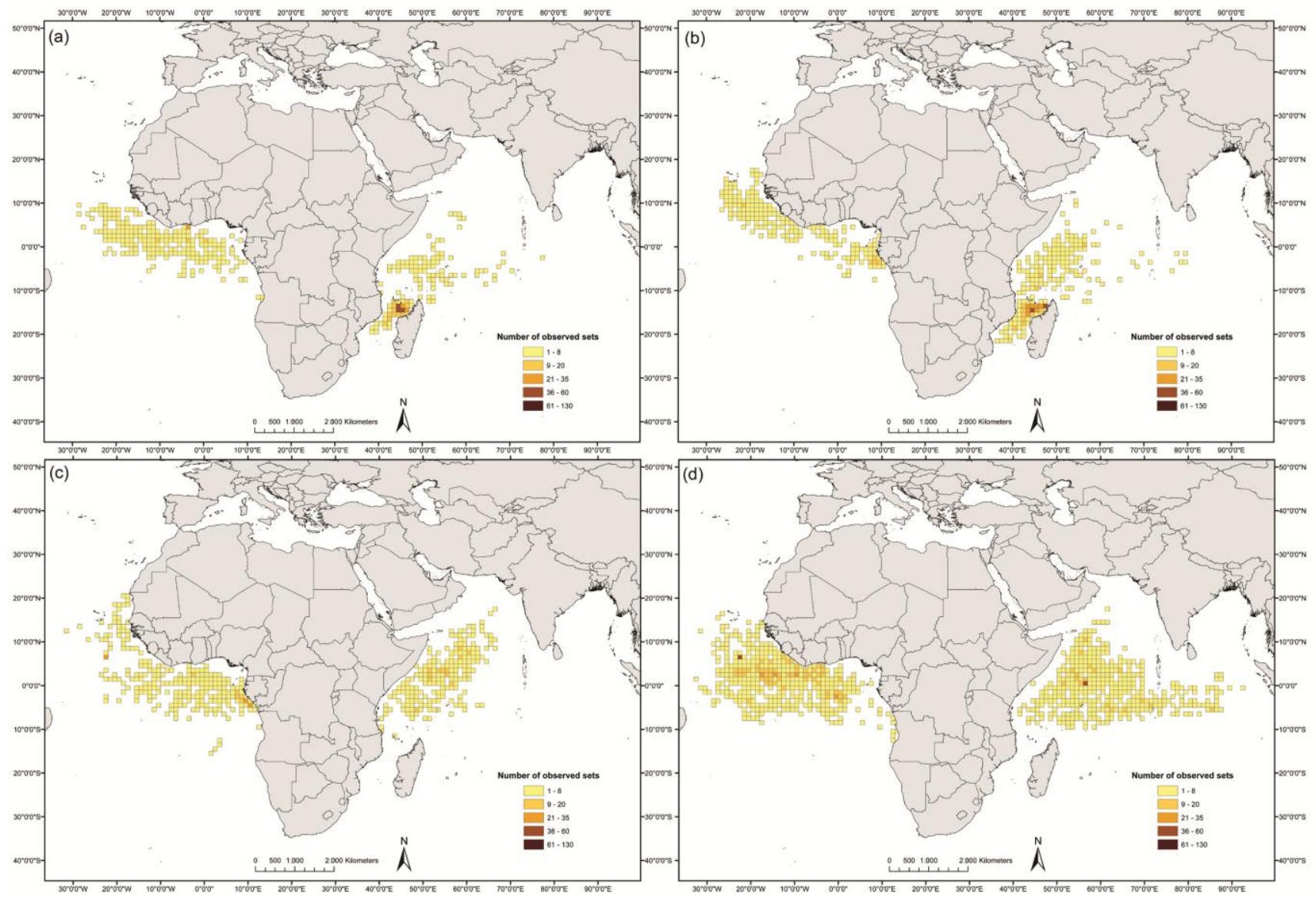

Figure A4 

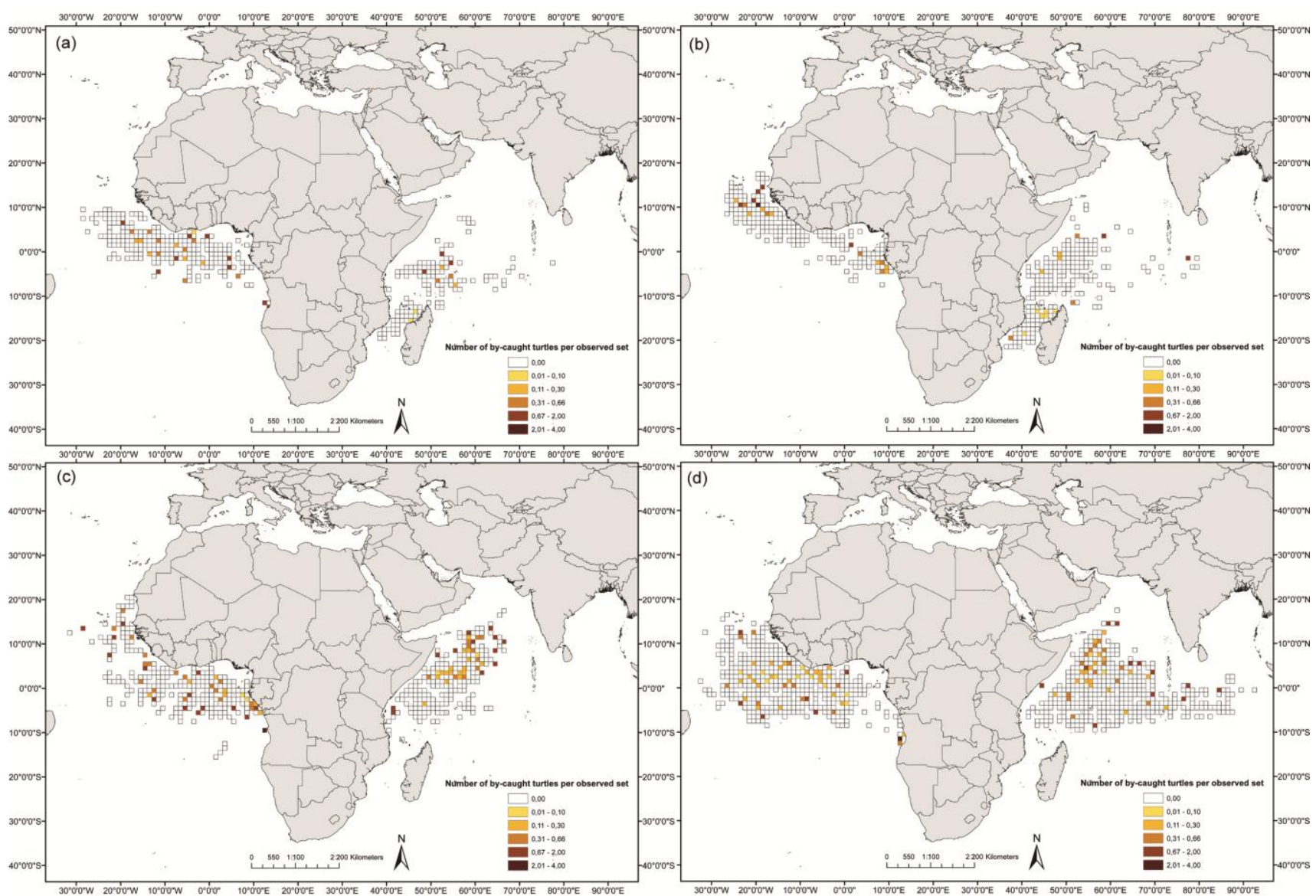

Figure A5
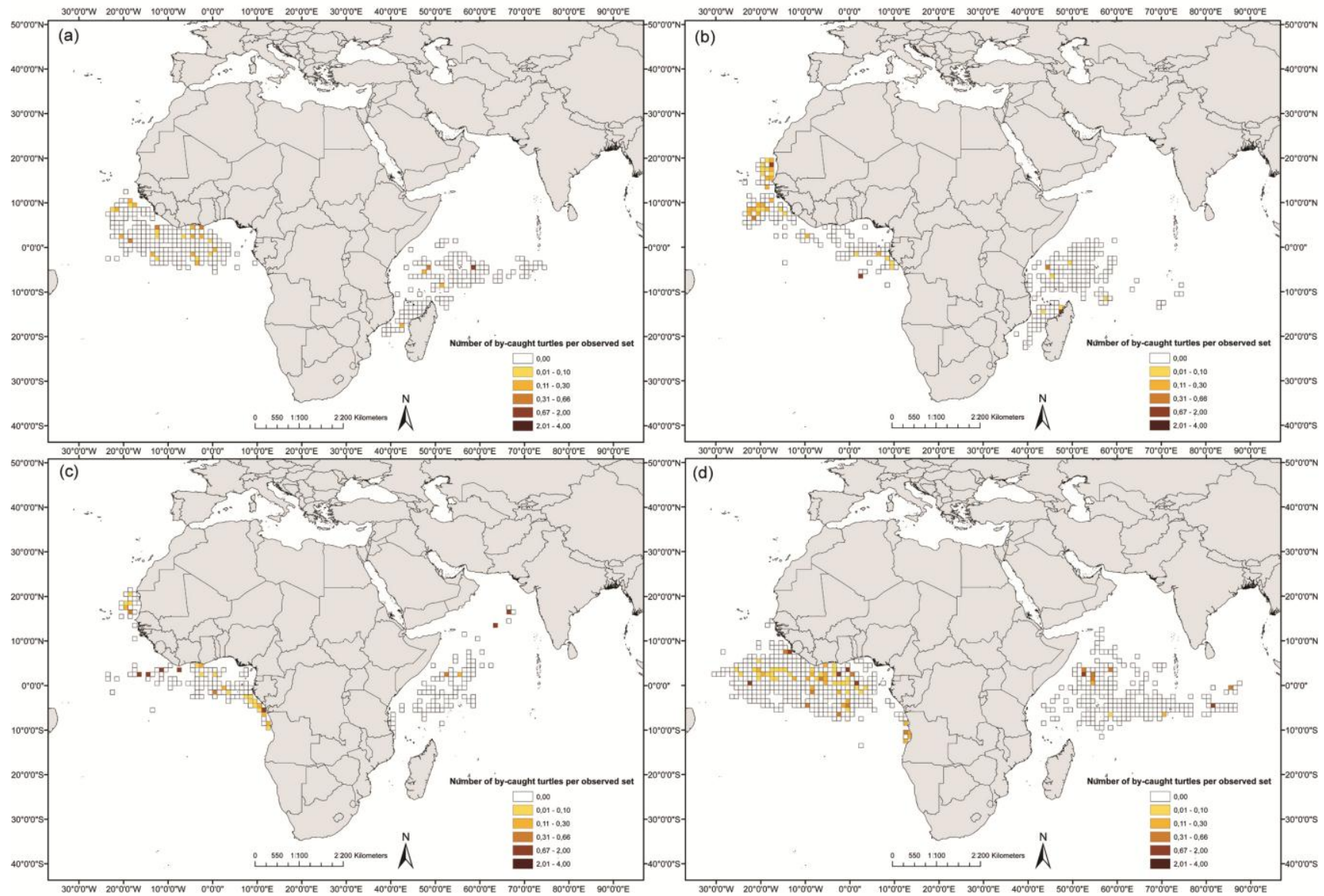

Figure A6 

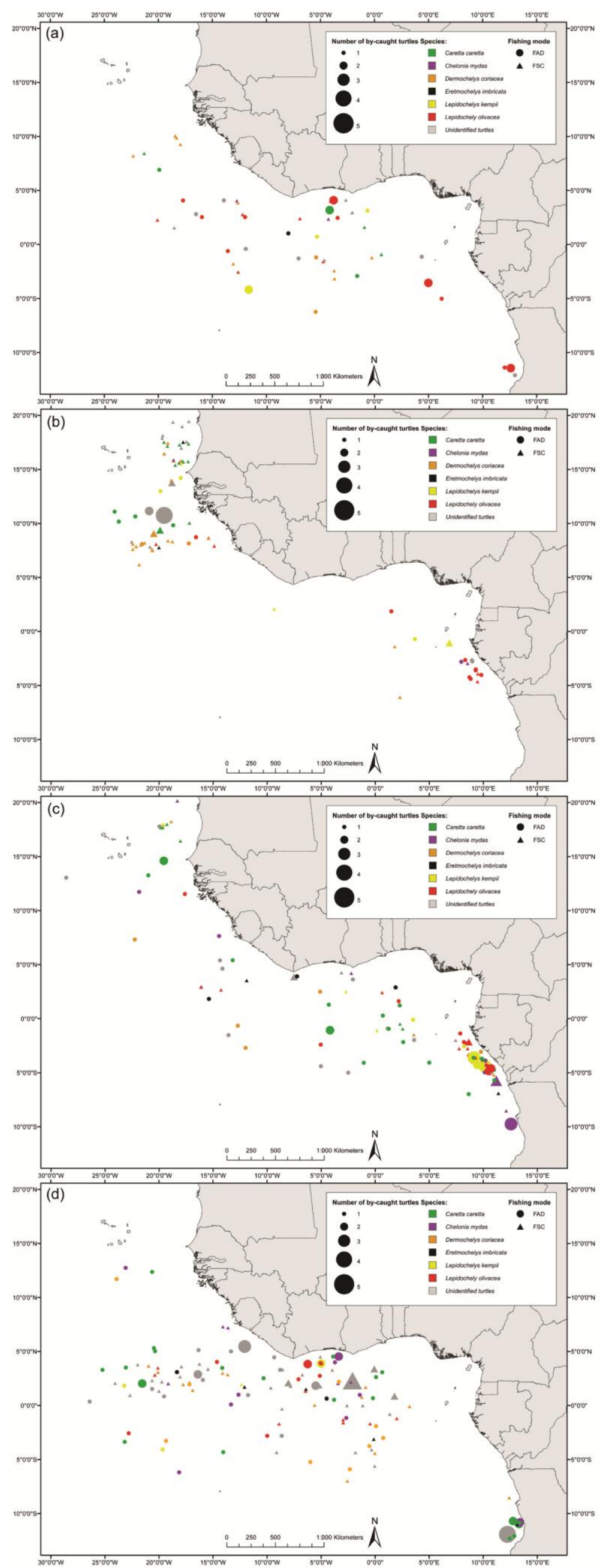

Figure A7 


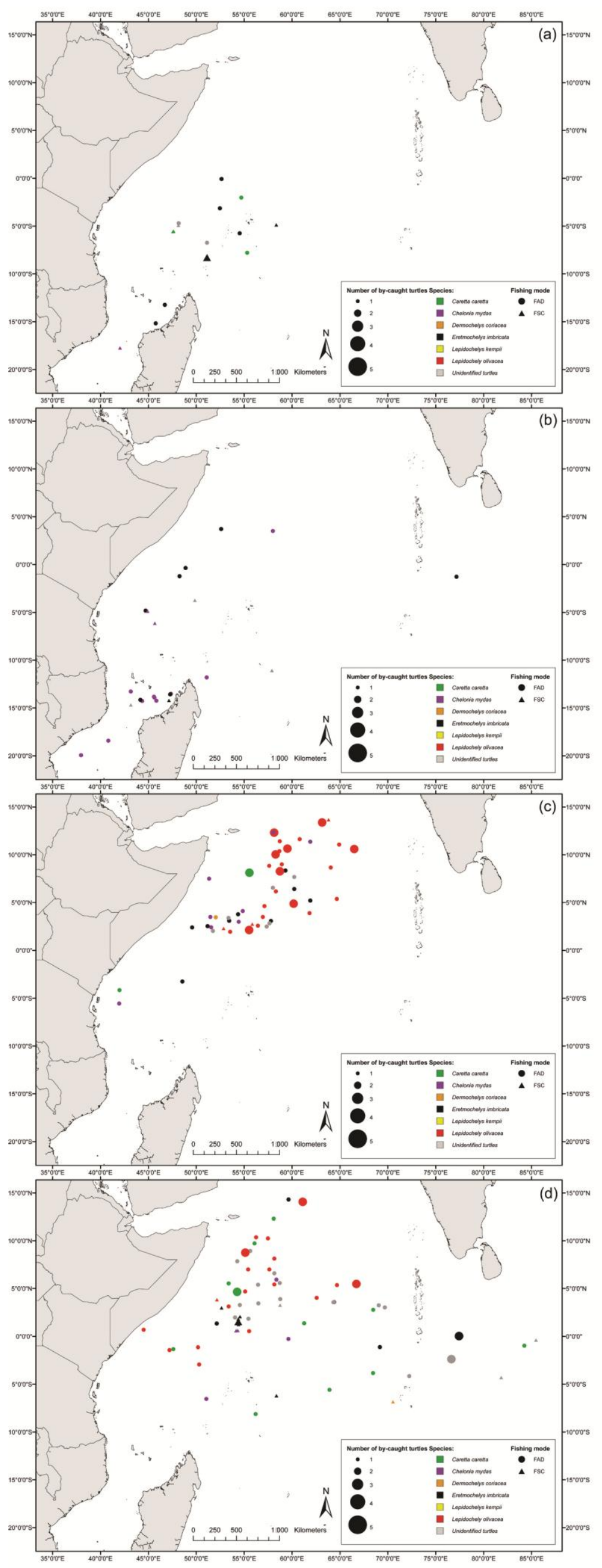

Figure A8 